Article

\title{
Study of the Impact of PV-Thermal and Nanofluids on the Desalination Process by Flashing
}

\author{
Samuel Sami ${ }^{1,2}$ \\ 1 Research Center for Renewable Energy, Catholic University of Cuenca, Cuenca 010150, Ecuador; \\ dr.ssami@transpacenergy.com \\ 2 TransPacific Energy, Inc., Las Vegas, NV 89183, USA
}

Received: 10 December 2019; Accepted: 19 January 2020; Published: 3 February 2020

\begin{abstract}
In this study, a mathematical and numerical modeling of the photovoltaic (PV)-thermal solar system to power the multistage flashing chamber process is presented. The proposed model was established after the mass and energy conservation equations written for finite control volume were integrated with properties of the water and nanofluids. The nanofluids studied and presented herein are $\mathrm{Ai}_{2} \mathrm{O}_{3}, \mathrm{CuO}, \mathrm{Fe}_{3} \mathrm{O}_{4}$, and $\mathrm{SiO}_{2}$. The multiple flashing chamber process was studied under various conditions, including different solar radiation levels, brine flows and concentrations, and nanofluid concentrations as well as flashing chamber temperatures and pressures. Solar radiation levels were taken as $500 \mathrm{w} / \mathrm{m}^{2}, 750 \mathrm{w} / \mathrm{m}^{2}, 1000 \mathrm{w} / \mathrm{m}^{2}$, and finally, $1200 \mathrm{w} / \mathrm{m}^{2}$. The nanofluid volumetric concentrations considered varied from $1 \%$ to $20 \%$. There is clear evidence that the higher the solar radiation, the higher the flashed flow produced. The results also clearly show that irreversibility is reduced by using nanofluid $\mathrm{Ai}_{2} \mathrm{O}_{3}$ at higher concentrations of $10 \%$ to $20 \%$ compared to water as base fluid. The highest irreversibility was experienced when water was used as base fluid and the lowest irreversibility was associated with nanofluid $\mathrm{SiO}_{2}$. The irreversibility increase depends upon the type of nanofluid and its thermodynamic properties. Furthermore, the higher the concentration (e.g., from $10 \%$ to $20 \%$ of $\mathrm{Ai}_{2} \mathrm{O}_{3}$ ), the higher the availability at the last flashing chamber. However, the availability is progressively reduced at the last flashing chamber. Finally, the predicted results compare well with experimental data published in the literature.
\end{abstract}

Keywords: desalination; flashing chamber; PV-thermal; nanofluids; numerical model; validation

\section{Introduction}

Water scarcity is a complex and difficult problem. Desalination uses a large amount of energy, and it is difficult to advocate for a technology that increases fossil fuel-based energy consumption. Remote coastal areas in the Middle East, Africa, and the Mediterranean and Caribbean islands are suffering from acute shortages of drinking water [1-3]. It is anticipated that by 2025, more than about $60 \%$ of the world's population will suffer from serious drinking water shortages [4]. Conventional desalination techniques, such as multi-stage flash (MSF) desalination, vapor compression (VC), reverse osmosis $(\mathrm{RO})$, membrane distillation (MD), and electrodialysis (ED), require significant thermal energy to function. As more places face water scarcity, desalination is considered as a possible answer. However, energy and financial requirements limit how widely that process can be used. We believe that solar energy is the logical response to these limitations and can power thermal and electrical desalination systems. Studies $[5,6]$ have shown that solar desalination can be achieved, in particular, in areas where solar intensity is high and there is a lack of fresh drinking water. Therefore, this research was undertaken to study the impact of solar energy and nanofluids on the desalination process.

Nannaronea et al. [7] presented a general model to simulate the multiple stage flash distillation (MSF) process. The model was implemented within the Camel-ProTM Process Simulator. Several 
validation tests were conducted to confirm that the model is an efficient tool for MSF plant design and prediction of the most important variables in the MSF process. Lumped parameter dynamic models were developed in Al-Fulaij's Ph.D. thesis [8] or using the MSF once through (MSF-OT) and the MSF brine circulation (MSF-BC) processes. The models were coded using the gPROMS modeling program. The model predictions for both MSF-OT and MSF-BC in steady state and dynamic conditions showed good agreement with data from existing MSF plants with an error less than $1.5 \%$. The methodology proposed in [9] provides a set of modular simulations of components that allow the creation of complex models used to optimize the full water desalination supply chain. The optimization scheme included mathematical programming (MP) models that were solved by an external MP solver for Saudi Arabia, which is considered the worldwide leader in desalinated water capacity.

Amer [10] reported on a steady-state mathematical model of the multi-effect thermal vapor compression (ME-TVC) desalination system. The ME-TVC desalination system in this paper was developed using the Engineering Equations Solver (EES) to evaluate the model system performance. The model validity was examined against three commercial ME-TVC units and the end results were good. In addition, a MATLAB algorithm solution was developed and used to solve model equations, where a different number of effects were tested to maximize the gain ratio of the process. A computational field model for the flashing process in the evaporation zone inside a flashing chamber with nanofluid-based solar collectors was developed by the author of [11] using two-phase volume of fluid (VOF) formulation. The model was then applied to investigate the effects of variations in the inlet brine flow rate and inlet brine temperature for both finite and infinite flashing process classifications. The predictions were analyzed to estimate MSF design factors, such as the non-equilibrium temperature difference and flashing efficiency.

An integrated system using a flashing desalination technique coupled with a nanofluid-based solar collector as a heat source was presented in [12] to study both the effect of different operating modes and that of the variation of functioning parameters and weather conditions on freshwater production using nanofluids. The flashing unit was produced using a similar construction design technique of a commercial multi-stage flashing (MSF) plant. Another objective of the reported developed mathematical model was to calculate the productivity of the system under different operating conditions.

A mathematical model for a multi-stage flash (MSF) desalination system with brine recirculation (BR) configuration was developed and presented by the authors of [13]. They described the heat source chosen for the BR-MSF as a nanofluid-based direct absorption solar collector (DASC), for which the numerical model was developed. Both systems, BR-MSF and DASC were coupled via a countercurrent flow heat exchanger. The overall performance of the combined system was determined in terms of gained output ratio, referred to as GOR. The conceptual design for a photovoltaic thermal $(\mathrm{PV} / \mathrm{T})$ solar panel has been developed and analyzed to control the inherent temperature increase of PV cells in order to increase electrical efficiency [14-17]. A hybrid solar panel was developed and presented by Yang et al. [1] and Sami [16,17] to integrate photovoltaic (PV) cells onto a substrate through a functionally graded material (FGM) with water tubes cast inside, through which water serves as both heat sink and solar heat collector.

In addition to the above literature review, it is evident that very limited research work has been published on the use of nanofluids in the desalination process, as well as the use of multi-stage flashing (MSF) chamber process modeling and simulation of sea water brine. Thermal and membrane desalination studies have been focused on evaporation processes using steam. The novel concept for the MSF presented in this paper implements PV-thermal solar panels using a hot heat transfer fluid with nanofluids in the MSF process. The main objective of this paper was to present a mathematical and numerical modeling on the use of nanofluids and a PV-thermal solar system to power the multi-stage flashing chamber thermal process. The model proposed was established after the mass and energy conservation equations of the flashing process were integrated with the thermal and thermophysical properties of the vapor and nanofluids at different volume fractions as well as solar radiation levels. 
The nanofluids studied were $\mathrm{Ai}_{2} \mathrm{O}_{3}, \mathrm{CuO}, \mathrm{Fe}_{3} \mathrm{O}_{4}$, and $\mathrm{SiO}_{2}$ at different volume fractions. The process of multi-stage flashing using PV-thermal solar panels and nanofluids was analyzed under different conditions of sea water (brine) salt concentration, brine flows, and temperatures, as well as nanofluid concentrations and solar radiation levels.

\section{Numerical Modeling}

\subsection{PV Model}

The solar photovoltaic panel is composed of various modules and each module consists of arrays and cells. The dynamic current output can be obtained as follows [14-17]:

$$
I_{P}=I_{L}-I_{o}\left[\exp \left(\frac{q\left(V+I_{P} R_{S}\right)}{A k T_{C}}-\frac{V+I_{P} R_{S}}{R_{s h}}\right)\right]
$$

$I_{p}$ : Output current of the Pv module;

$I_{L}$ : Light generated current per module;

$I_{0}$ : Reverse saturation current per module;

$V$ : Terminal voltage per module;

$R_{S}$ : Diode series resistance per module;

$R_{s h}$ : Diode shunt resistance per module;

$q$ : Electric charge;

$k$ : The Boltzman constant;

$A$ : Diode ideality factor for the module.

The AC power of the inverter output $P(t)$ is calculated using the inverter efficiency $\eta_{\text {inv }}$, output voltage between phases, neutral $V_{f n}$ and for single-phase current $I_{o}$ and $\cos \varphi$ as follows:

$$
P(t)=\sqrt{3} \eta_{i n v} V_{f n} I_{0} \cos \varphi
$$

\subsection{PV-Thermal Model}

It is assumed, in this model, that all PV cells behave the same; therefore, this model can be applied to the whole PV solar panel. This model is an extension of the work that has been presented by Sami and Campoverde [17] where the thermal heat absorbed by the PV solar cell can be calculated by the following equation:

$$
Q_{\text {in }}=\alpha_{a b s} G S_{p}
$$

where

$\alpha_{a b s}$ : Overall absorption coefficient;

G: Total Solar radiation incident on the PV module;

$S_{p}$ : Total area of the PV module.

Meanwhile, the PV cell's temperature is computed from the following heat balance as per Sami and Martin [18]:

$$
m C_{p_{-} \bmod u l e} \frac{d T_{C}}{d t}=Q_{\text {in }}-Q_{\text {conv }}-Q_{\text {elect }}
$$

where

$T_{C}$ : PV Cell Temperature;

$m C_{p \_ \text {module }}$ : Thermal capacity of the PV module;

$t$ : time;

$Q_{i n}$ : Energy received due to solar irradiation; 
$Q_{\text {conv }}$ : Energy loss due to Convection;

$Q_{\text {elect }}$ : Electrical power generated.

Readers interested in the detailed calculations of the terms in the above equation are advised to consult references $[17,18]$.

\subsection{Multistage Flashing Chamber Model}

In this section, we present a mathematical and numerical modelling on the use of nanofluids and PV-thermal solar to power the multistage flashing chamber thermal (MSF) process, as shown in Figure 1. In this figure, the brine is preheated by the nanofluid circulating in the PV-thermal loop where the heat dissipated from the PV solar panel is absorbed by the circulating heat transfer fluid, as shown in the figure. The flashing process occurs in the flashing chamber where the flashed vapor is generated and condensed on the heat exchanger that is cooled down by the incoming brine flow. The distilled condensed vapor is collected and the brine flow is circulated to the next flashing chamber where the same flashing process is repeated. The model proposed was established after the mass and energy equations coupled with the state equations of the nanofluids and water as the base fluid at different solar radiations. This numerical process was repeated for each of the flashing chambers. In the following section, we present the mass and energy equations of the brine flow in the flashing chamber.

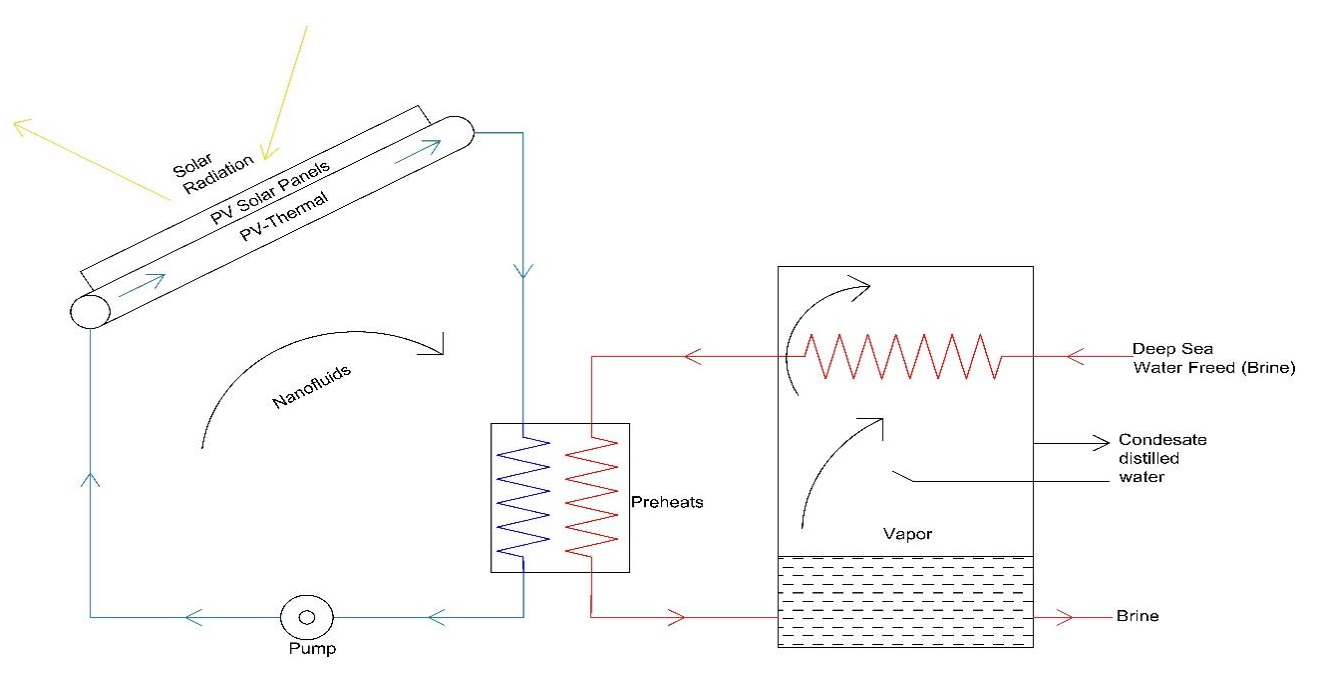

Figure 1. PV-Thermal integrated flashing chamber process.

Each flashing chamber is considered as discrete control volume and has a constant volume; therefore, by applying the first law of thermodynamic to the control volume, the mass balance and energy balance across the flashing chamber can be given by the following equations, respectively [7]:

$$
\begin{gathered}
\Sigma m_{\text {in }}-\Sigma m_{\text {out }}=0 \\
\Sigma e_{\text {in }}-\Sigma e_{\text {out }}=0
\end{gathered}
$$

where $m$ and $e$ are the mass and energy entering and leaving the flashing chamber control volume.

The brine sea water mass balance across the preheater is

$$
m_{B i}-m_{B o}=0
$$

where $m_{C B i}$ and $m_{B o}$ are the brine mass flow entering and leaving the preheater, respectively.

The brine concentration entering and leaving are given by the mass balance equation:

$$
m_{B i} S_{B i}-m_{B o} S_{B o}=0
$$


The distilled condensed mass balance is

$$
m_{C o}-m_{C i}-m_{\text {Dbrine }}=0
$$

where $m_{D b r i n e}$ is the distilled mass of vapor condensed as per Figure 1.

The preheater energy balance is

$$
\left(m_{\text {Dbrine }}+\gamma m_{B i}\right) \Delta H_{\text {evap }}-m_{B i} C p_{\text {brine }}\left(T_{C B o}-T_{C B i}\right)=0
$$

where the distillate flashing fraction $\gamma$ is

$$
\gamma=\frac{C p_{\text {cond }} * D T_{\text {Stage }}}{\Delta H_{\text {evap }}}
$$

where $D T_{\text {Stage }}$ and $\Delta H_{\text {evap }}$ are the stage temperature difference and heat of evaporation, respectively.

\section{Nanofluid Heat Transfer Fluid}

The different equations reported in [16-18] were used to calculate the thermophysical properties of the nanofluids, such as the specific heat, thermal conductivity, viscosity and density using the law of mixtures. The thermophysical, thermodynamic and heat transfer properties of nanofluids are determined in terms of the volumetric concentration of the nano particles as per the following equation:

$$
\alpha_{\text {total }}=\alpha_{\text {particles }}+\alpha_{\text {base fluid }}
$$

where $\alpha$ represents the thermophysical property of a particular nanofluid.

The nanofluid thermal and thermophysical properties, $\alpha_{\text {total }}$, can be calculated as follows:

$$
\alpha_{\text {total }}=\alpha_{\text {base fluid }}+\alpha_{\text {particles }}(\Phi)
$$

where $\Phi$ represents the nano particles volumetric concentration.

The thermal conductivity and thermal diffusivity and density of the nanofluids are related as follows [16-18]:

$$
\lambda=\alpha \delta C_{p}
$$

where $C_{p}$ is the specific heat, $\alpha$ is the thermal diffusivity, $\lambda$ and $\delta$ represent the thermal conductivity and density, respectively.

Readers interested in further details on the calculations of the nanofluids thermophysical and thermodynamic properties are advised to consult references [16-24]. In particular, these references discussed the impact of the nanofluid concentrations on the thermophysical properties of the nanofluids used in this study. Moreover, the scope of this study is rather focused on the discussion of the MSF process using the PV-Thermal with nanofluids as heat transfer fluids than the thermophysical properties of the nanofluids, since they are discussed elsewhere: [16-24].

Finally, the availability and irreversibility of the flashing process are calculated as:

$$
A_{q}=\Sigma\left(1-T_{a m b} / T_{J}\right) Q_{J}
$$

where $A_{q}$ is the flow availability change under steady state condition per stage, and $A_{q}$ is the availability transfer due to $Q_{J}$, the heat transfer between the control volume and its surroundings. $T_{a m b}$ and $T_{J}$ are the ambient temperature and the Flashing chamber temperature, respectively.

The availability destruction i.e., the irreversibility of the flashing process per stage can be determined as follows:

$$
I_{j}=T_{a m b} x S_{J}
$$


where $S_{J}$ represents the entropy of the flashing process at each stage.

\section{Numerical Procedure}

The model that describes the energy conversion process in the PV-Th panels, integrated desalination by flashing chamber process concept using nanofluids is presented in Equations (1)-(16). The flow diagram in Figure 2 was established to solve the aforementioned system of equations for mass and energy taking place during the flashing chamber process. The calculation starts with the input of the parameters of the PV-Thermal solar panel, thermal tubes, desalination chamber parameters, nano particles, $\mathrm{Ai}_{2} \mathrm{O}_{3}, \mathrm{CuO}, \mathrm{Fe}_{3} \mathrm{O}_{4}$ and $\mathrm{SiO}_{2}$ and the heat transfer fluid. The system of equations was integrated using the finite-difference formulations to determine the behavior of the process at each flashing chamber. Iterations were performed using MATLAB iteration techniques until a converged solution was reached with less than 0.05 . With the knowledge of the solar radiation, the mass flow rate of the nanofluid circulating in the thin tubes welded to the PV solar collector can be determined. Then, the thermophysical properties and the heat transfer characteristics of the base fluid, water, and nanofluids at different concentrations are determined, as well as the mass and energy in the flashing chamber control volume. This was accomplished by solving the finite-difference formulation of the aforementioned system of equations. Then, the parameters describing the behavior of PV-Thermal solar panels, flashing chamber process were determined at different conditions. Finally, the individual and hybrid system efficiencies, availability and irreversibility, which represents the availability destruction in the process, were calculated.

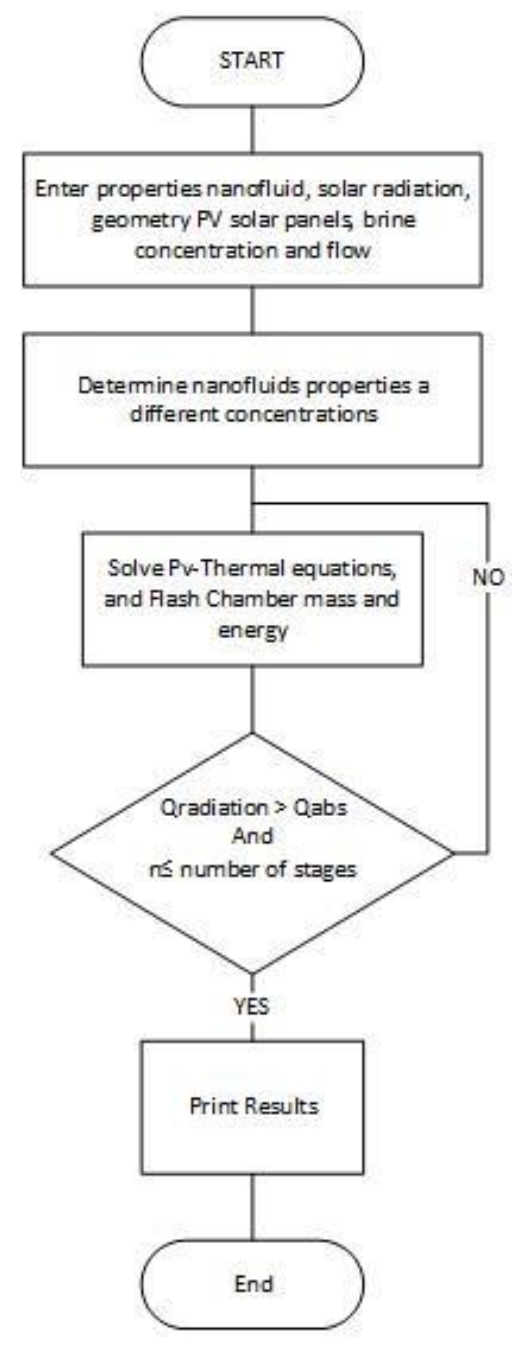

Figure 2. Logic diagram for the numerical solution. 


\section{Discussion and Analysis}

The aforementioned system of Equations (1)-(16) was numerically solved using the finite-difference formulation for the desalination flashing process using the different nanofluids at different concentrations and water as the base heat transfer fluid. In the following sections, we present the predicted results under different inlet conditions, such as solar insolation, brine and heat transfer fluid flow rates from the PV-Thermal, heat transfer fluid temperatures for the various nanofluids, $\mathrm{Ai}_{2} \mathrm{O}_{3}, \mathrm{CuO}, \mathrm{SiO}_{2}$ and $\mathrm{Fe}_{3} \mathrm{O}_{4}$ at different volumetric concentrations.

In particular, Equations (1)-(4) were solved to predict the dynamic total power generated, efficiencies of the PV solar panels. Moreover, the key important parameters of a hybrid system composed of a novel combined concept of a photovoltaic-thermal solar panel hybrid system were determined using Equations (5) through (16). As reported and discussed by Sami [16-18], it is evident from the results presented on the dynamic PV-Thermal studies that the higher the solar radiations, the higher the thermal and hybrid efficiencies. It is also observed that the hybrid efficiency exhibits lower values than the thermal efficiency since the PV solar panel efficiency is significantly lower than the thermal efficiency.

Furthermore, the PV simulation study results presented in references [16] through [18] show that the higher the solar radiation, the faster the increase in the PV cell temperature. Consequently, they also show that the higher the solar radiation, the higher the PV power and PV amperage. It is imperative that the designer of the PV panel considers that the cell temperature is impacted by the solar radiation as well as the ambient conditions. Finally, it was found that the model prediction compared fairly with the PV data at different conditions.

Sami $[16-18,22,23]$ reported that nanofluids, such as $\mathrm{CuO}, \mathrm{Fe}_{3} \mathrm{O}_{4}$ and $\mathrm{SiO}_{2}$, have received significant attention in the literature when the PV-Thermal hybrid system is used. It is evident from the results presented in these references that the nanofluid $\mathrm{CuO}$ has the highest characteristic performance among the other nanofluids and water as the base heat transfer fluid circulating in the PV-Thermal solar collector system. This can obviously be attributed to the higher thermodynamic and thermophysical and heat transfer properties of the nanofluid $\mathrm{CuO}$ that contribute to outperformance over the other nanofluids. In addition, Sami $[16-18,22,23]$ reported that the PV-Thermal efficiency is enhanced with higher concentrations of this nanofluid at constant solar radiation.

Moreover, it was assumed, in the numerical simulation using Equations (5)-(16), that 10 flashing chambers were used and the brine flow is heated up by the heat transfer fluid preheater, as shown in Figure 1. A salt concentration of $5 \%$ was used in the brine flow and $60 \mathrm{~F}$ ambient temperature. In addition, 100 PV solar panels were also assumed with 300 watts per each PV solar panel. Solar radiations were taken as $500 \mathrm{w} / \mathrm{m}^{2}, 750 \mathrm{w} / \mathrm{m}^{2}, 1000 \mathrm{w} / \mathrm{m}^{2}$ and finally, $1200 \mathrm{w} / \mathrm{m}^{2}$.

Since nanofluid $\mathrm{Ai}_{2} \mathrm{O}_{3}$ is one of the most common nanofluids studied and reported in the literature, Figures 3-10 were constructed to demonstrate the impact of using this nanofluid at concentrations of $10 \%$ and $20 \%$ on the behavior of the most important key parameters of the flashing process. In addition, the behavior of nanofluid Ai2O3 was compared to water as base fluid, at different solar radiations ranging between 500 to $1200 \mathrm{w} / \mathrm{m}^{2}$, respectively. In addition, the important thermodynamic parameters, such as the irreversibility and availability, were calculated and shown in Figures 9 and 10. Examining the results presented in Figures 3 and 4 suggests that the higher the nanofluid concentration as a heat transfer fluid, the lower the salt $\%$ in the flashed flow leaving the set of the flashing chambers compared to water as the base heat transfer fluid used in the brine preheater. On the other hand, it can also be seen from the figures that the higher the solar radiation, the lower the salt $\%$ in the flashed flow. This can be attributed to the fact that higher solar radiation results in higher temperature of the heat transfer fluid and consequently, the brine flow in the preheater entering the flashing chambers. In addition, it was found that the higher the heat transfer fluid temperatures, the higher the brine flow temperatures and the higher the amount of the distilled water evaporated or flashed. It can also be noticed from the results that the salt $\%$ in brine was increased progressively in the flashing chambers until reaching its maximum value at the final chamber. 


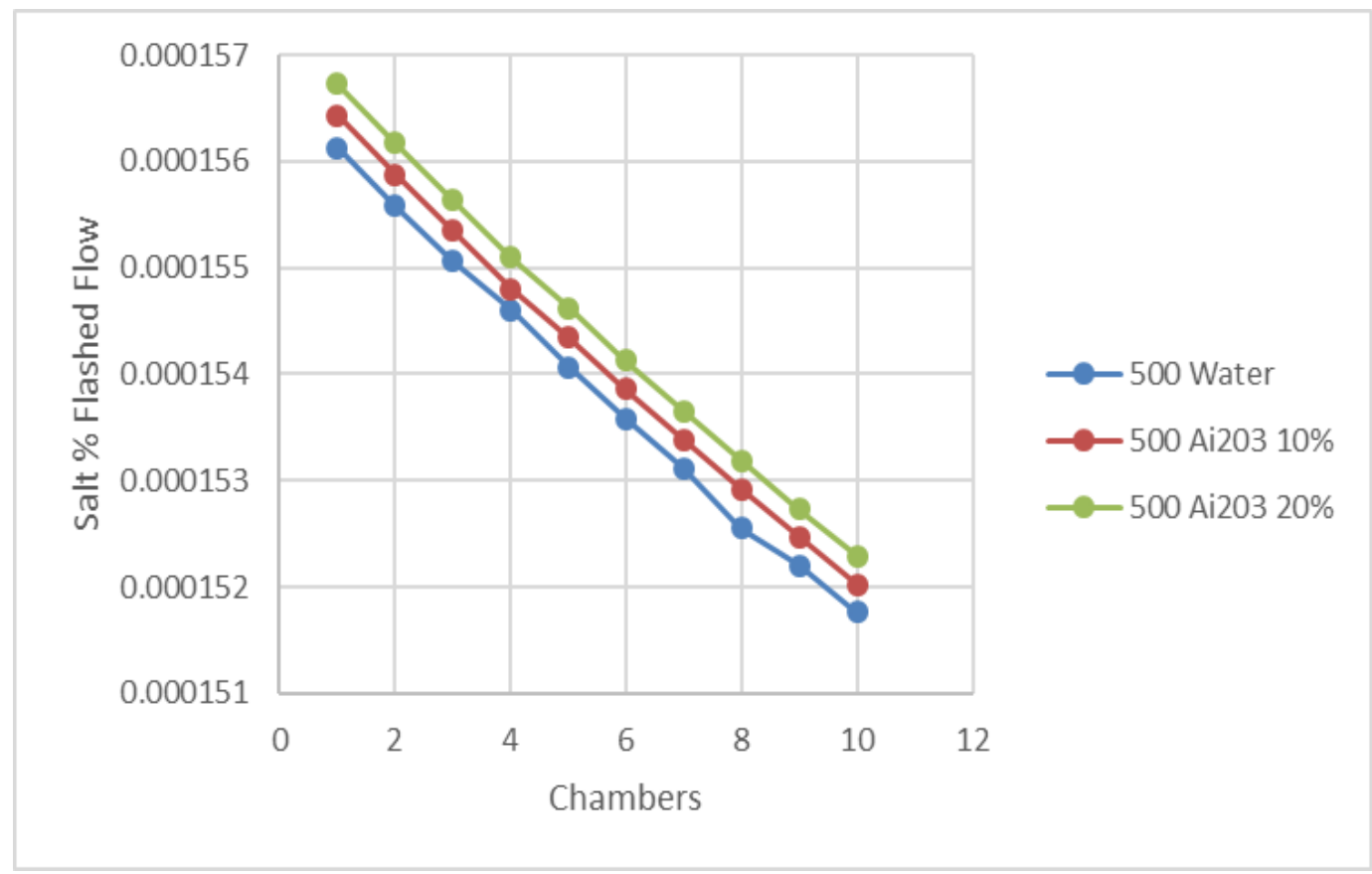

Figure 3. Salt $\%$ in flashed flow at $500 \mathrm{w} / \mathrm{m}^{2}$.

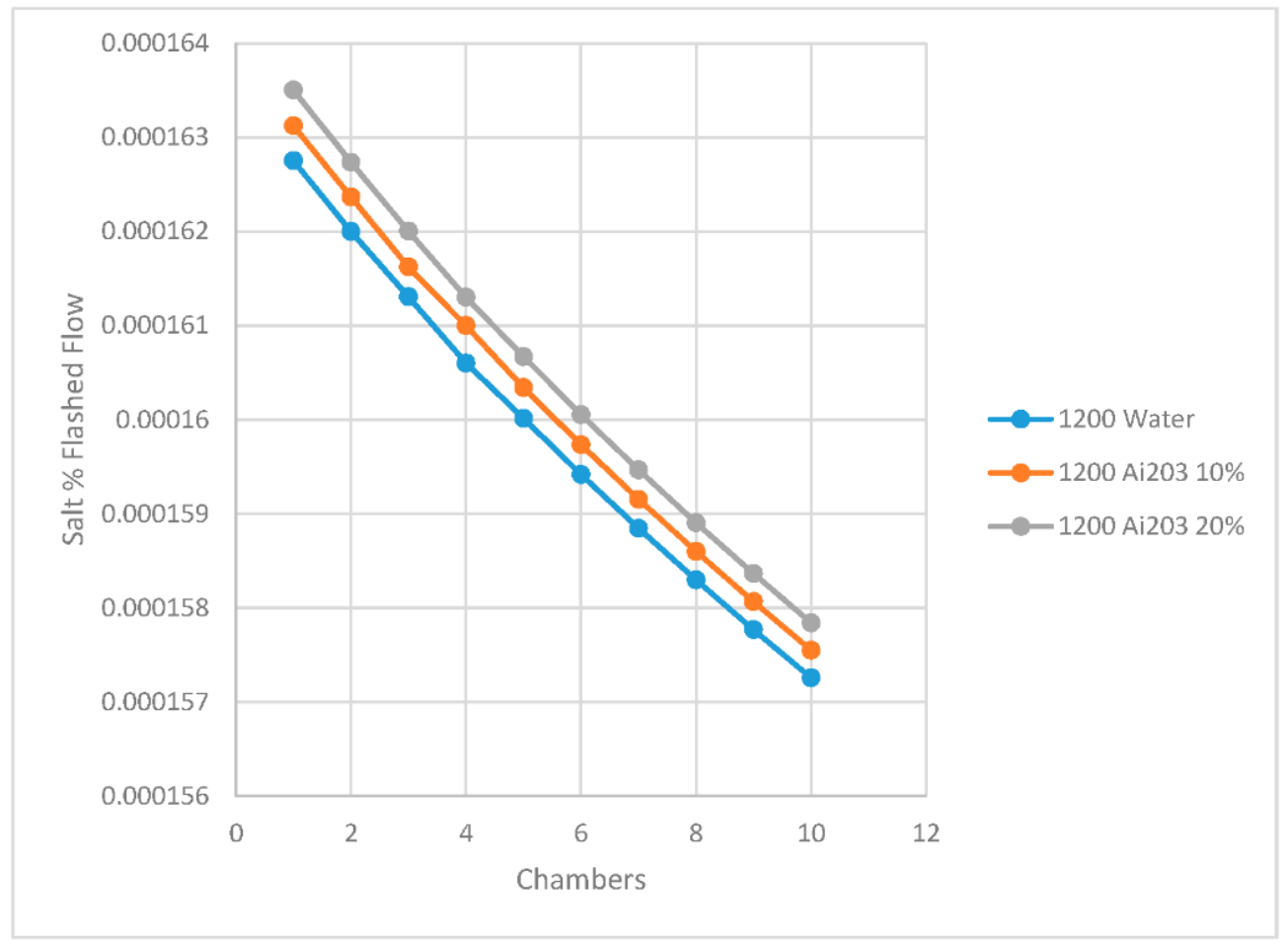

Figure 4. Salt $\%$ in flashed at $1200 \mathrm{w} / \mathrm{m}^{2}$. 


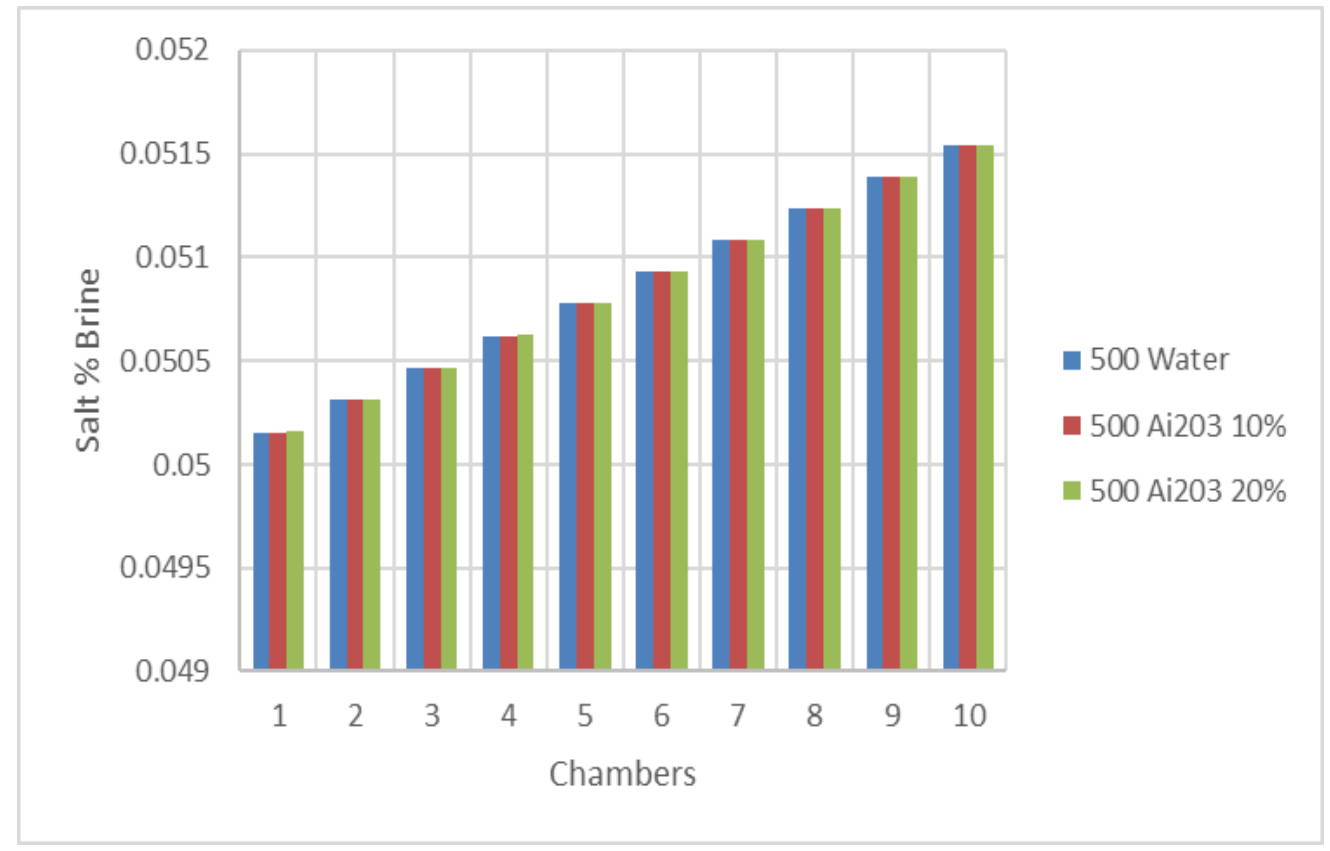

Figure 5. Salt $\%$ in brine at $500 \mathrm{w} / \mathrm{m}^{2}$.

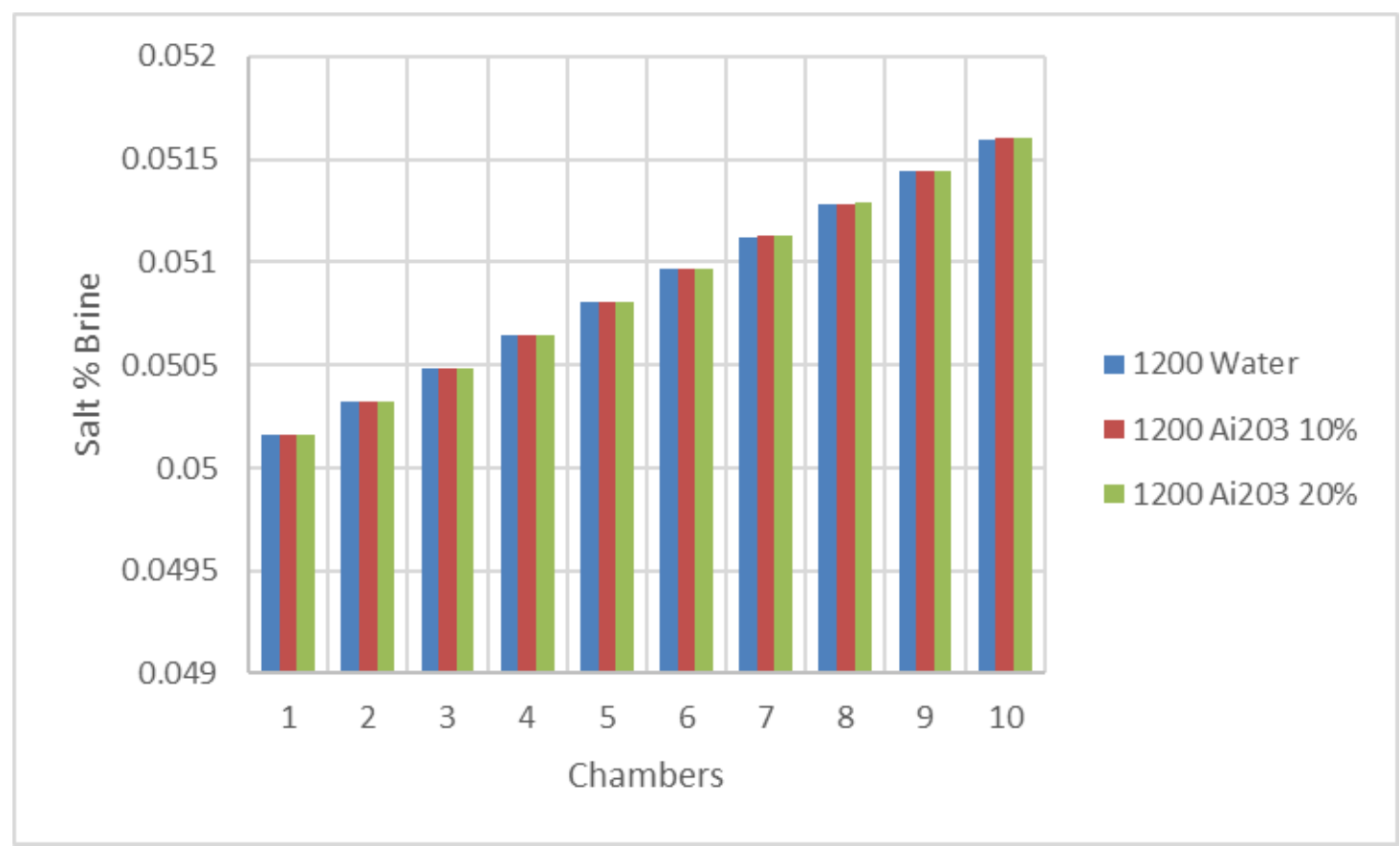

Figure 6. Salt $\%$ in brine at $1200 \mathrm{w} / \mathrm{m}^{2}$. 


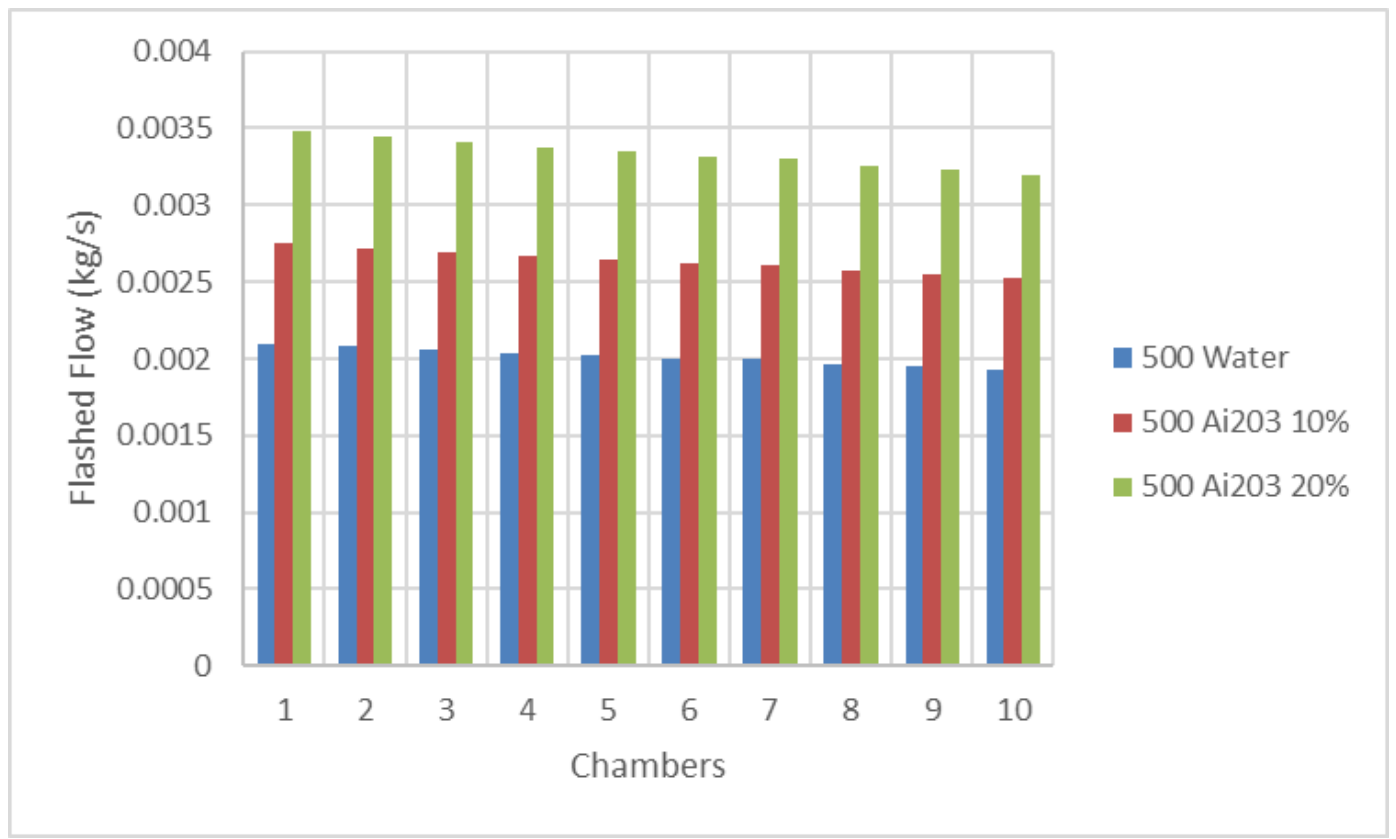

Figure 7. Flashed flow at $500 \mathrm{w} / \mathrm{m}^{2}$.

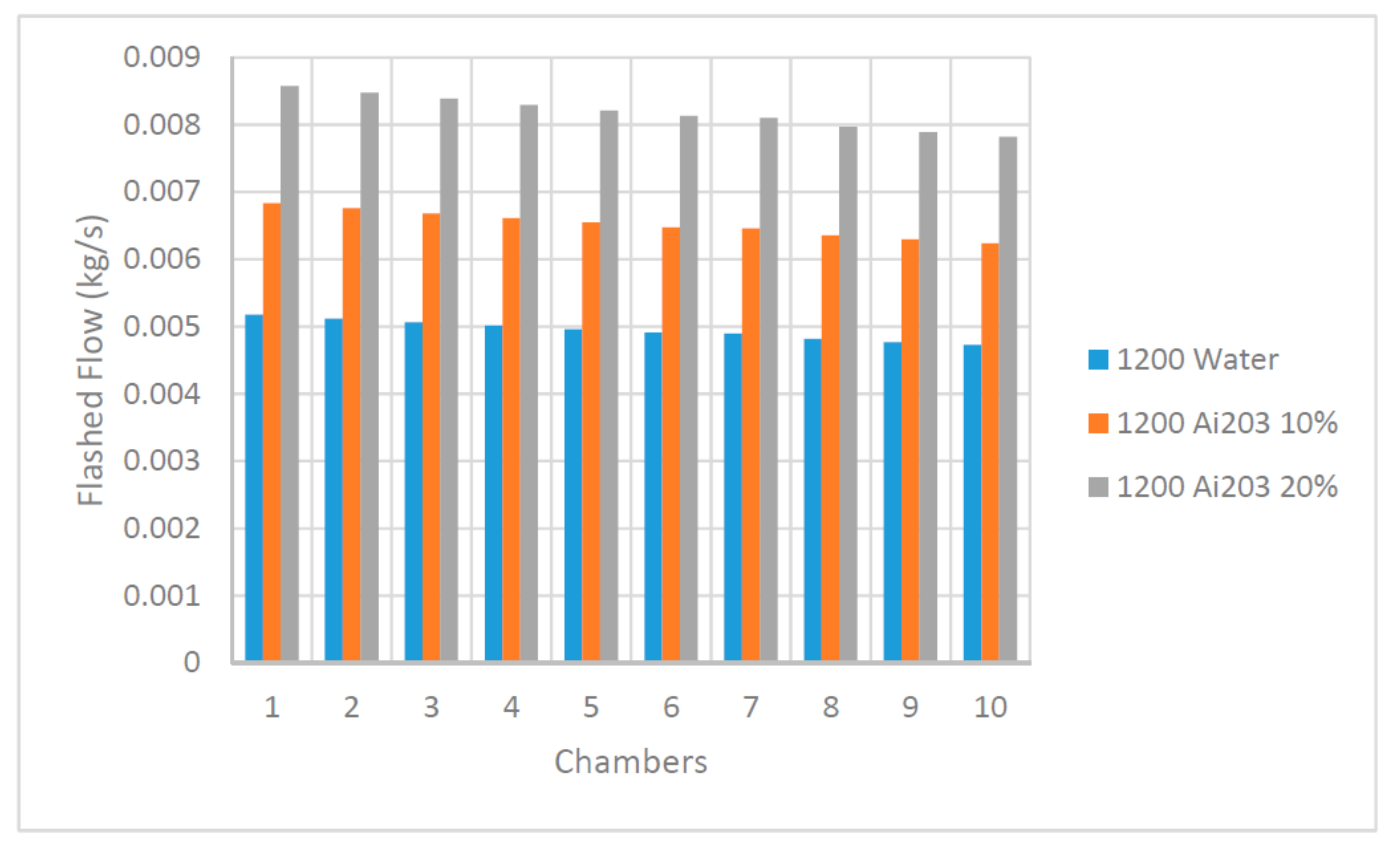

Figure 8. Flashed flow at $1200 \mathrm{w} / \mathrm{m}^{2}$. 


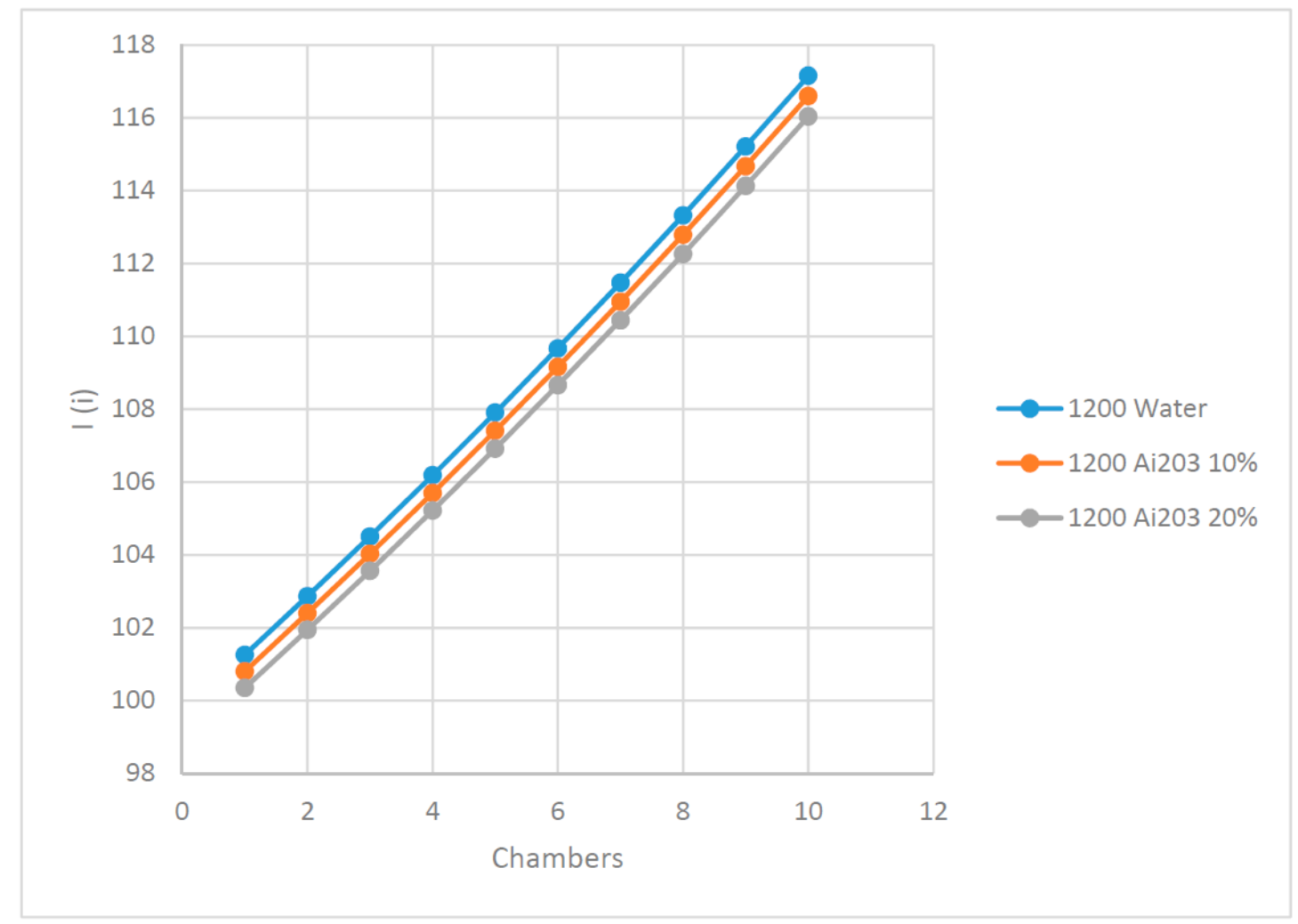

Figure 9. Irreversibility at $1200 \mathrm{w} / \mathrm{m}^{2}$.

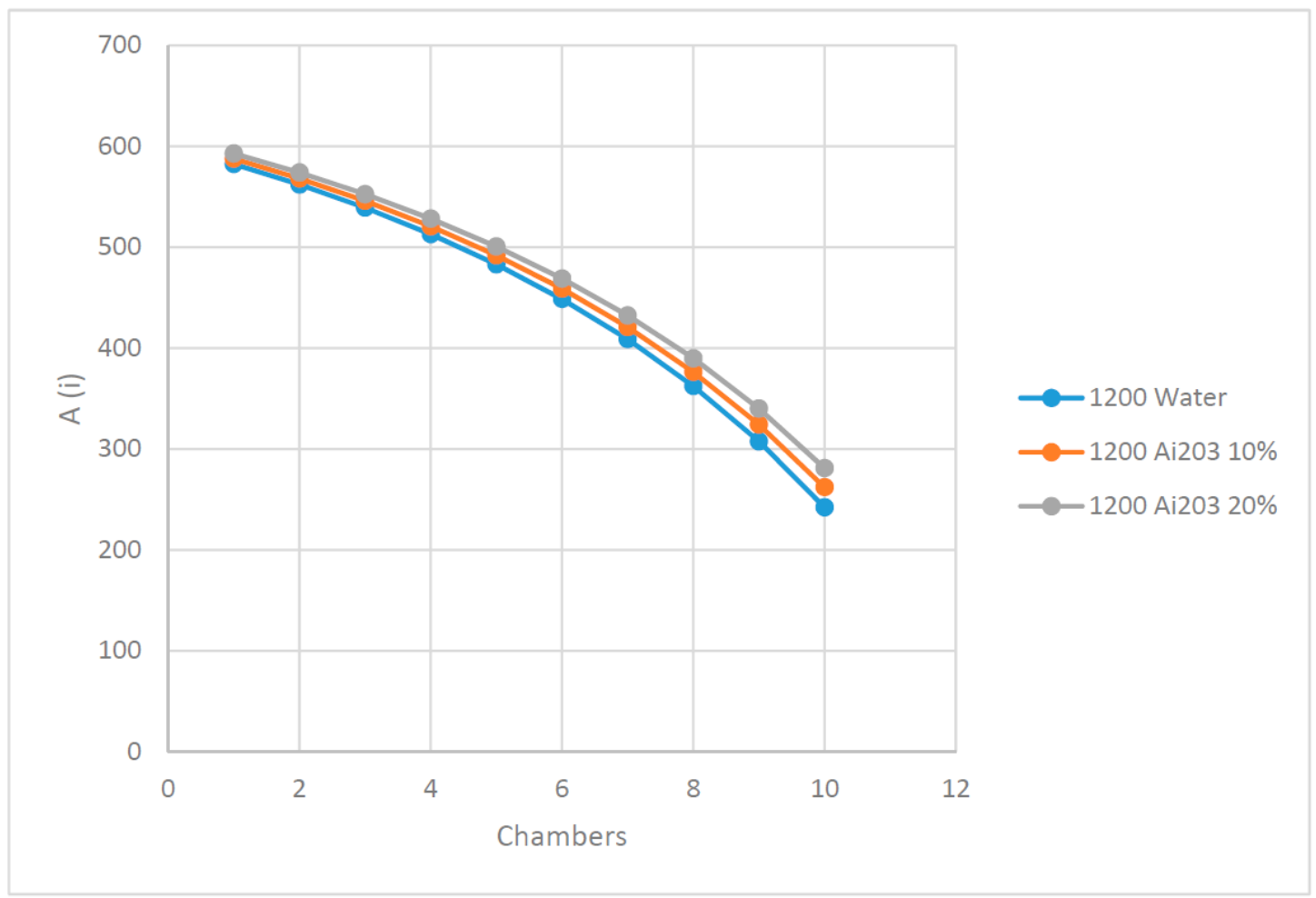

Figure 10. Availability at $1200 \mathrm{w} / \mathrm{m}^{2}$.

Figures 7 and 8 display the changes in the flashed flow in each flashing chamber, at different solar radiations, where it can be seen that the flashed flow was reduced progressively and reached its lowest value at the last flashing chamber. The amount of the produced distillate decreased along the 
different stages and consequently, the flash temperature and pressure profiles decreased; this is due to the increase of the heat of vaporization at lower saturation temperatures and therefore, a lower amount of vapor was extracted from brine. In fact, the data in these figures show that the higher the solar radiation, the higher the temperature; this caused the distillation rate to rise, since a larger amount of vapor can be extracted from saltwater. The results also show that the higher the solar radiation, the higher the flashed flow per chamber. In addition, these results also demonstrated that the higher the nanofluid $\mathrm{Ai}_{2} \mathrm{O}_{3}$ concentration, the higher the flashed flow produced during the flashing process compared to water as base heat transfer fluid.

In thermodynamics, changes in the state or process of a system cannot be restored to its initial state by changes in the properties of the system without expenditure of energy [21]. An irreversible process increases the entropy of the system in question. The second law of thermodynamics can be used to determine the irreversibility of a process as per Equation (16). In the thermodynamic process, the energy is lost to the surroundings in the form of irreversible energy. However, the remaining amount of energy is defined as the available energy in the process [21]. This thermodynamic principal was applied in the current study of the flashing chamber process, as expressed in Equations (15) and (16) to assess the lost and available energy in the process under question. In particular, Figures 9 and 10 were constructed to demonstrate the variation of irreversibility and the availability at a solar radiation of $1200 \mathrm{w} / \mathrm{m}^{2}$ during the flashing process at each stage. The results displayed in these figures clearly show that the irreversibility was reduced by using nanofluid $\mathrm{Ai}_{2} \mathrm{O}_{3}$ at a higher concentration compared to water as base heat transfer fluid. Furthermore, the higher the concentration of $\mathrm{Ai}_{2} \mathrm{O}_{3}$, the higher the availability observed at the last flashing chamber. However, the availability was progressively reduced toward the last flashing chamber.

Furthermore, Figures 11 and 12 were constructed to demonstrate the benefits of using a high concentration of nanofluids $\mathrm{Ai}_{2} \mathrm{O}_{3}, \mathrm{CuO}, \mathrm{SiO}_{2}$ and $\mathrm{Fe}_{3} \mathrm{O}_{4}$ on the values of the salt $\%$ in the flashed flow exiting at each flashing chamber. It is quite evident from the data presented in these figures that the salt $\%$ was reduced at the last flashing chamber with the increase of the concentration of nanofluids. In particular, nanofluid $\mathrm{SiO}_{2}$ showed the highest reduction of the salt $\%$ in the flashed flow exiting the last chamber.

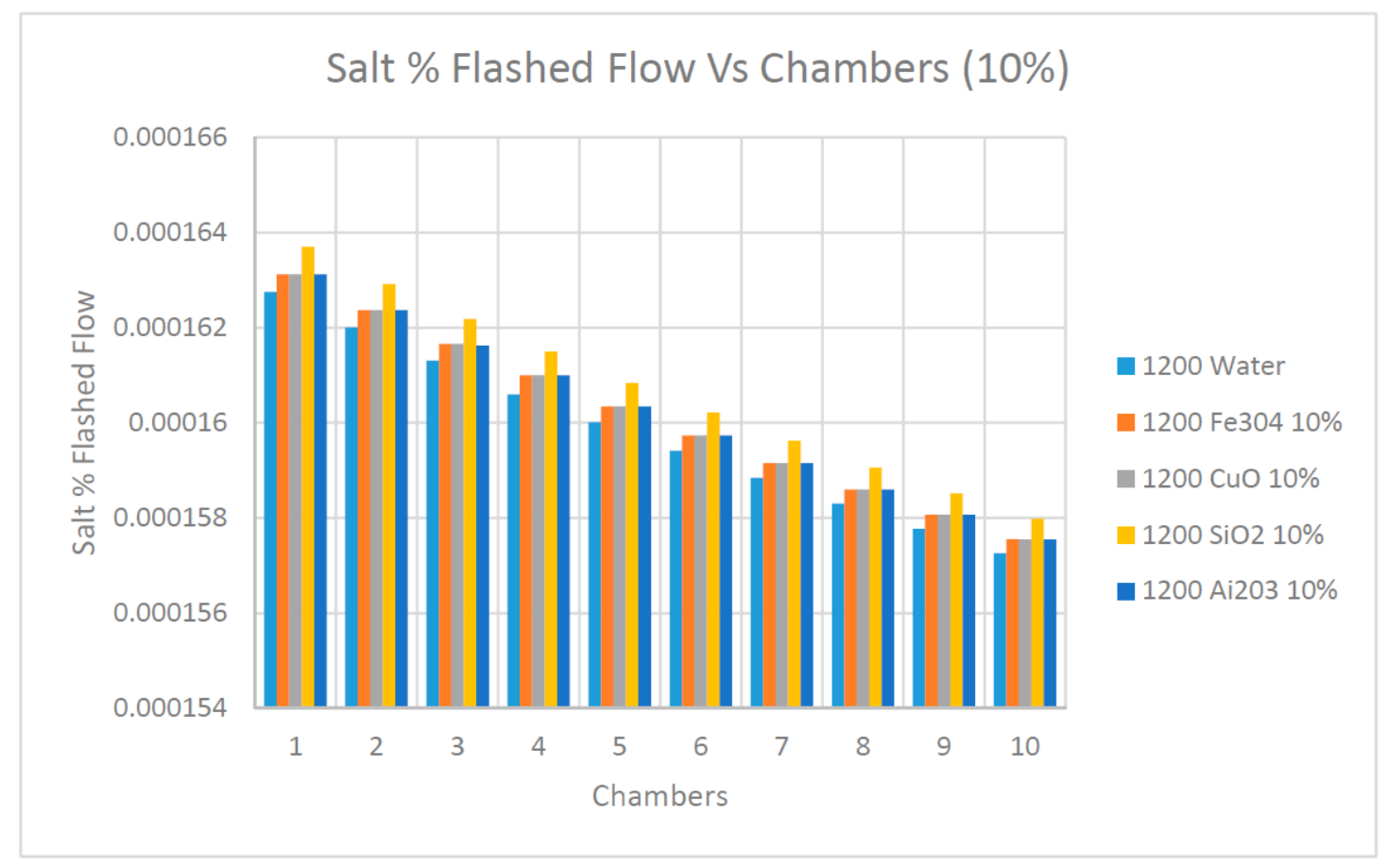

Figure 11. Salt $\%$ flashed flow at $1200 \mathrm{w} / \mathrm{m}^{2}$. 


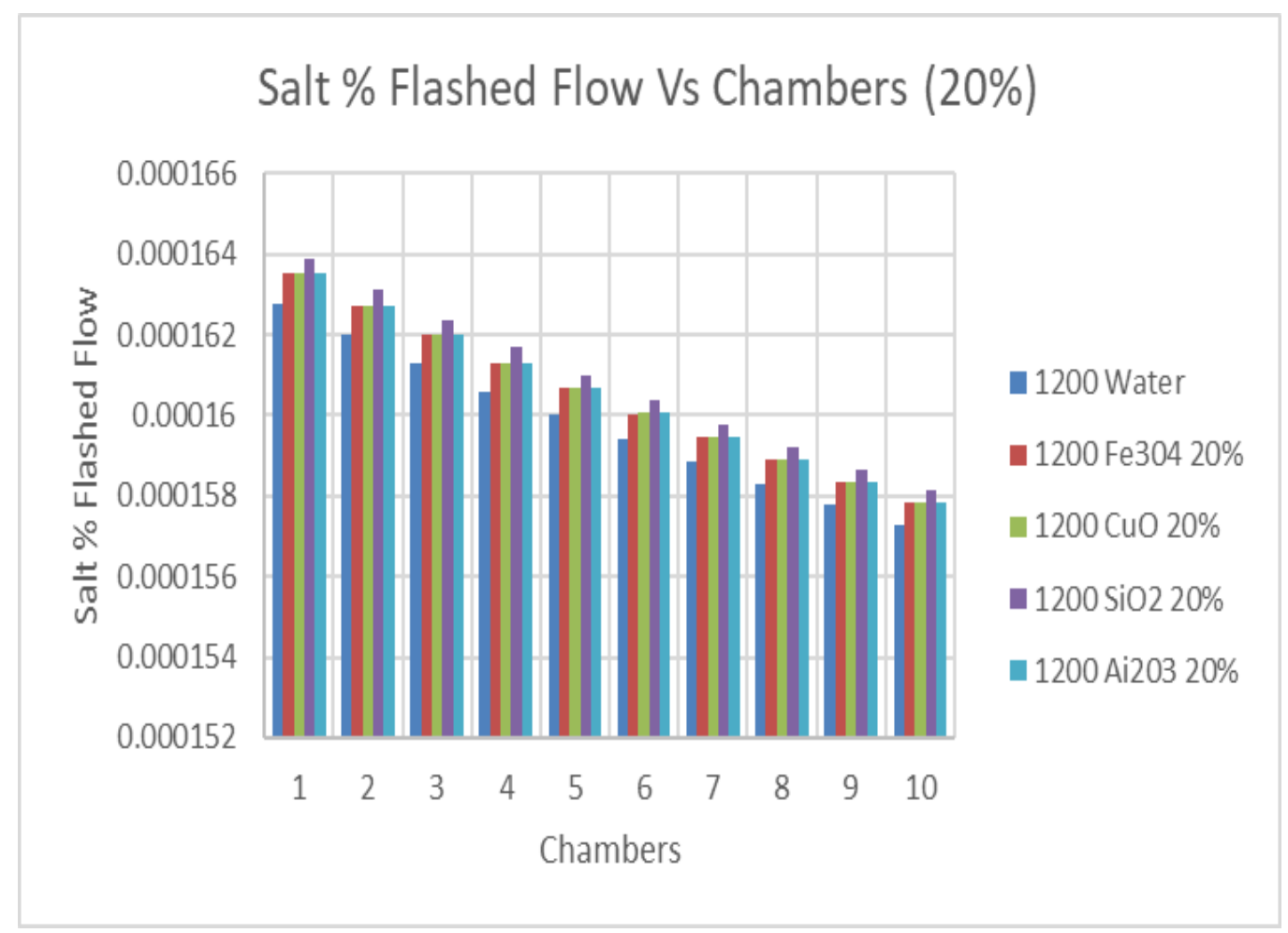

Figure 12. Salt $\%$ flashed flow at $1200 \mathrm{w} / \mathrm{m}^{2}$.

Figures 13 and 14 show that the salt percentage in the brine flow at $1200 \mathrm{w} / \mathrm{m}^{2}$ was increased progressively across the chambers with the use of the nanofluids; however, the increase of the percentage of salt in the brine flow was slightly impacted by the concentration of the nanofluids. In addition, it appears from the results plotted in these figures that the salt percentage in the brine flow was independent of the type of nanofluids within the water as the base fluid.

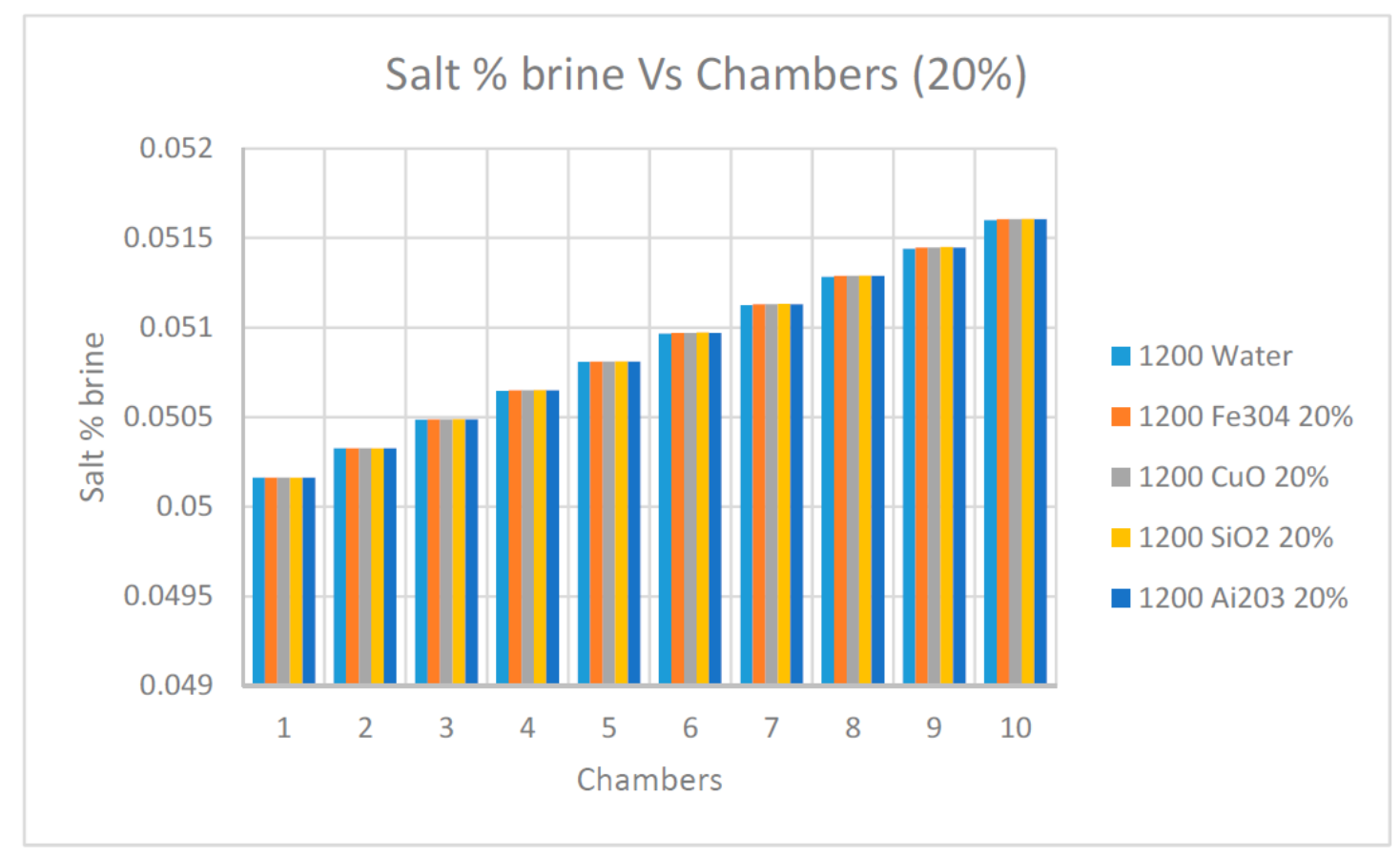

Figure 13. Salt $\%$ brine at $1200 \mathrm{w} / \mathrm{m}^{2}$. 


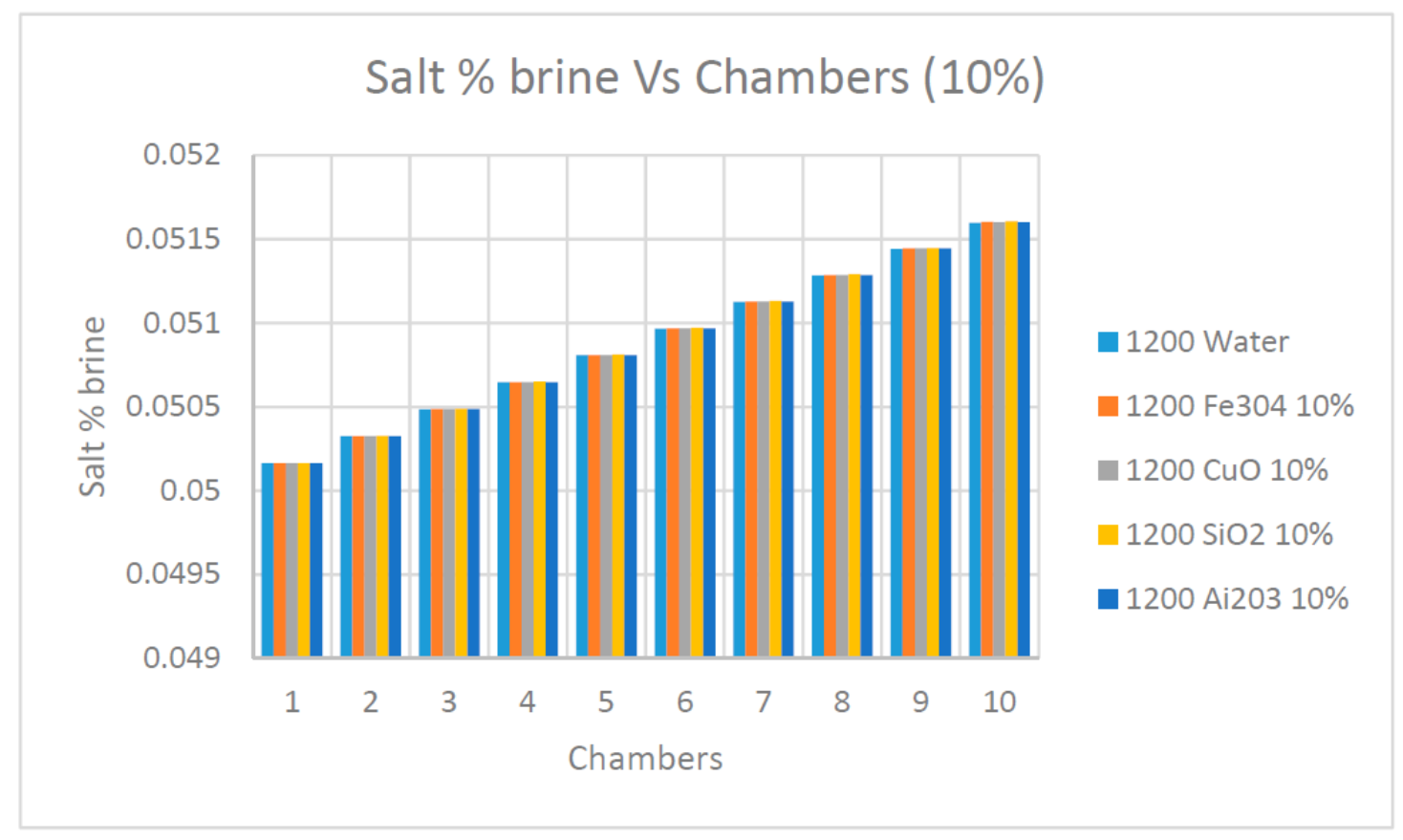

Figure 14. Salt \% brine at $1200 \mathrm{w} / \mathrm{m}^{2}$.

On the other hand, Figures 15 and 16 display the development of the flashed flow profile at the different flashing chambers. In general, the data in these figures show that the flashed flow was progressively reduced until reaching the lowest value at the last chamber. This is due to the increase of the heat of vaporization at lower saturation temperatures and therefore, less amount of vapor is extracted from brine. As expected, the data show that the higher the concentration of the nanofluid, the higher the amount of flashed flow produced. Further analysis of the data observed clearly demonstrates that the use of the nanofluid $\mathrm{Ai}_{2} \mathrm{O}_{3}$ produced the highest amount of flashed flow during this process.

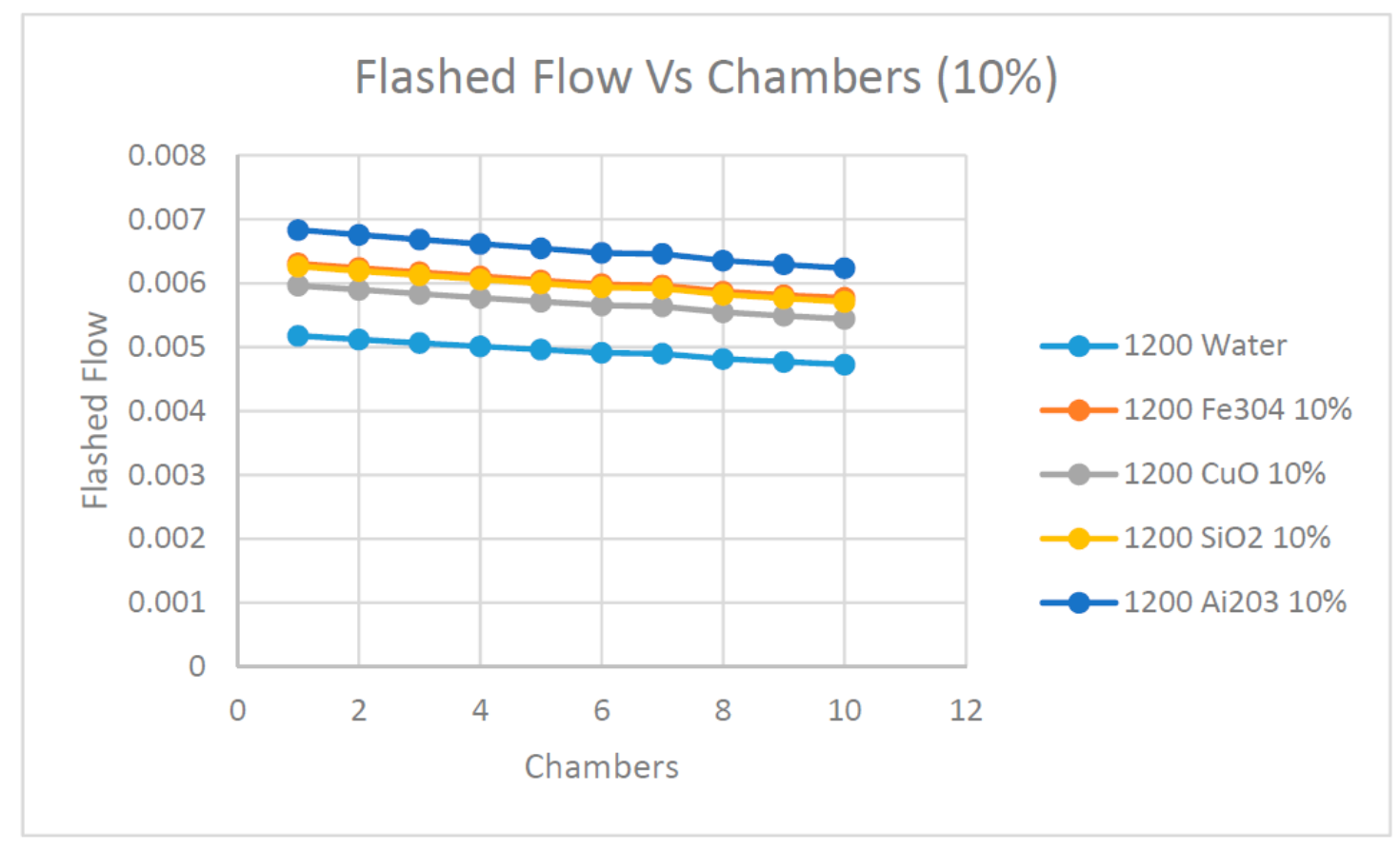

Figure 15. Flashed flow $(\mathrm{kg} / \mathrm{s})$ at $1200 \mathrm{w} / \mathrm{m}^{2}$ and $10 \%$ concentration. 


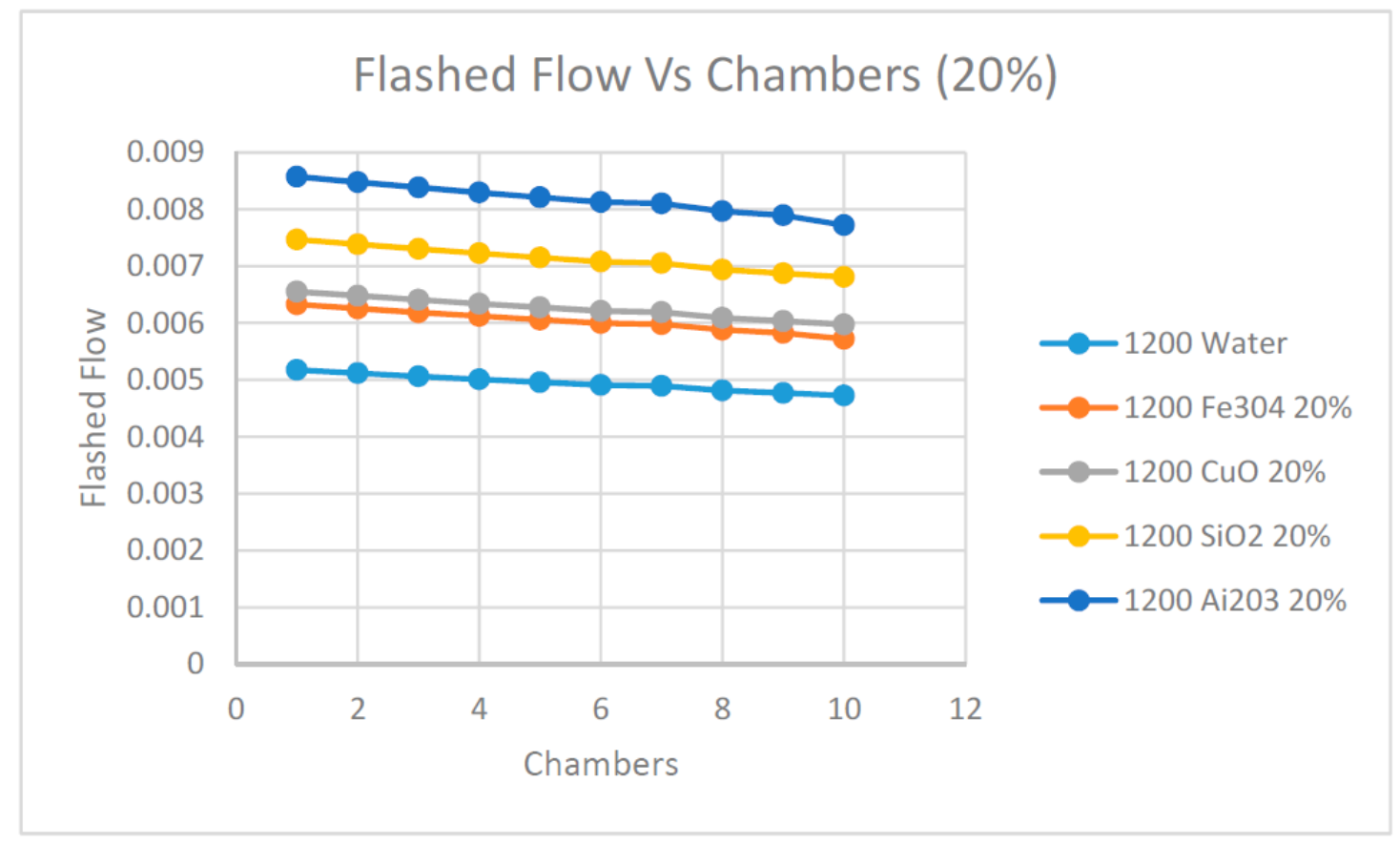

Figure 16. Flashed flow $(\mathrm{kg} / \mathrm{s})$ at $1200 \mathrm{w} / \mathrm{m}^{2}$ and $20 \%$ concentration.

In order to study the influence of the solar radiation on the flashed flow, Figures 17 and 18 are presented. There is clear evidence that the higher the solar radiation, the higher the flashed flow produced. This is clearly demonstrated at both concentrations of the nanofluids in the figures. Moreover, these figures show that nanofluid $\mathrm{Ai}_{2} \mathrm{O}_{3}$ produced the highest flashed flow among the nanofluids under investigation and water as the base heat transfer fluid. This observation is significant since using the nanofluid $\mathrm{Ai}_{2} \mathrm{O}_{3}$ can enhance the production of flashed flow three to four times over the water as the base fluid.

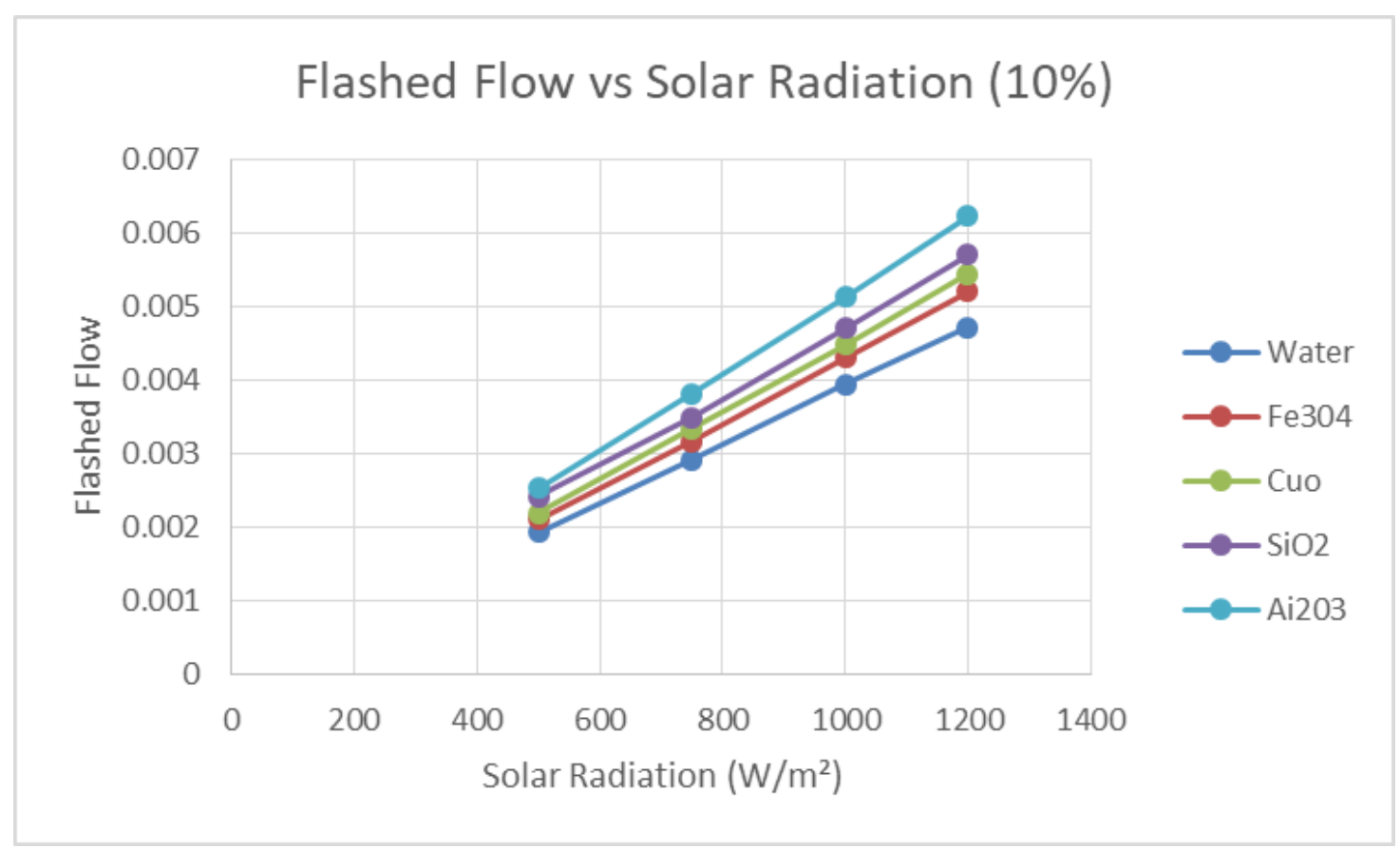

Figure 17. Flashed flow $(\mathrm{kg} / \mathrm{s})$ at $10 \%$ volumetric concentration. 


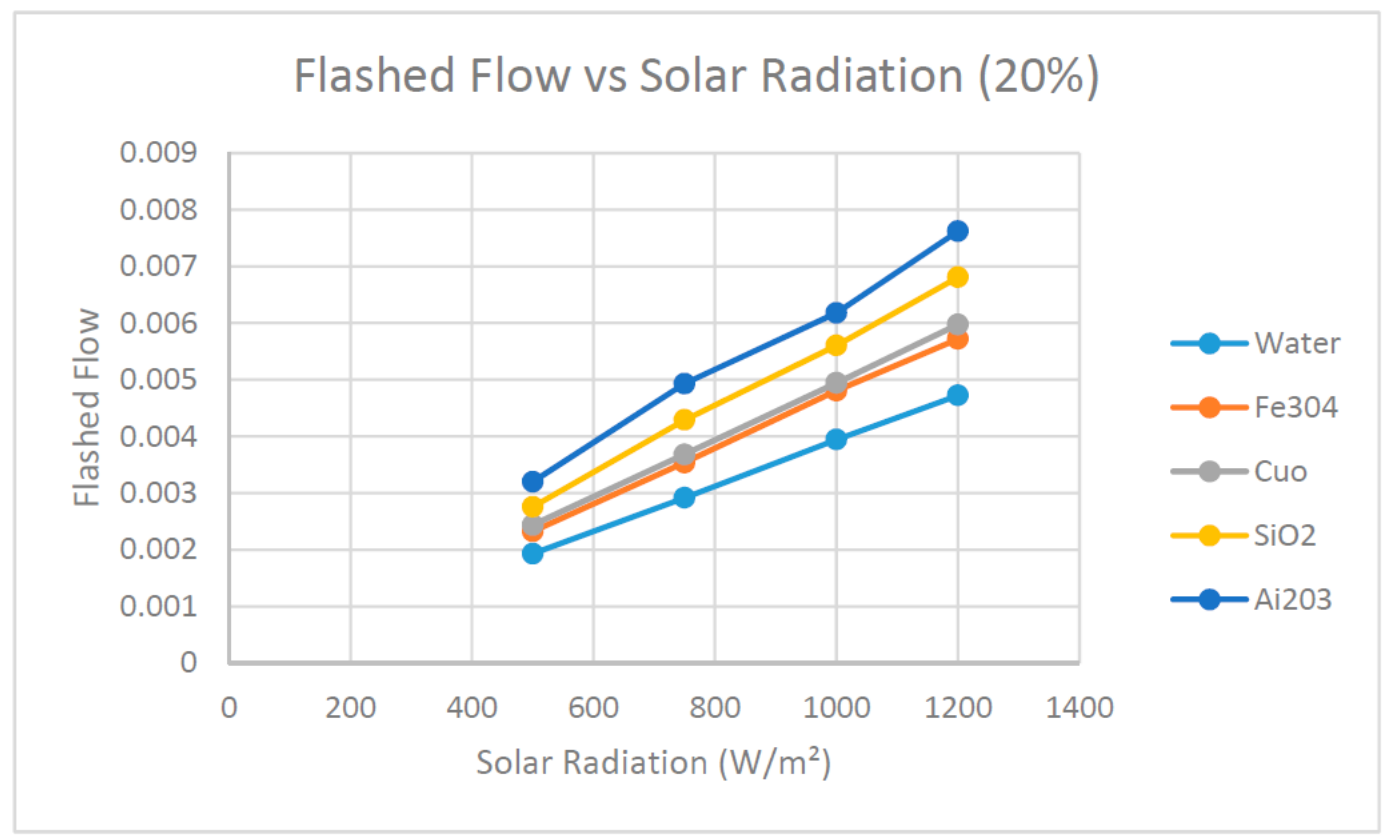

Figure 18. Flashed flow $(\mathrm{kg} / \mathrm{s})$ at $20 \%$ volumetric concentration.

Figures 19-22 explain the impact of the increase of the concentrations of nanofluids on the irreversibility and availability of the desalination flashing process, chamber by chamber at $1200 \mathrm{w} / \mathrm{m}^{2}$ solar radiation. Analyzing the results presented in these figures clearly shows that the irreversibility calculated by Equation (16) was significantly influenced by the type of nanofluids used compared to the base water as the heat transfer fluid. In addition, as expected the irreversibility increased progressively across the different chambers until reaching the maximum at the last chamber. The highest irreversibility was experienced when water was used as base fluid and the lowest irreversibility was associated with nanofluid $\mathrm{SiO}_{2}$. The irreversibility's increase depends upon the type of nanofluid and their thermodynamic properties. Moreover, it appears that the concentration of the nanofluid did not have a significant impact on the changes of irreversibility across the various chambers during the flashing process.

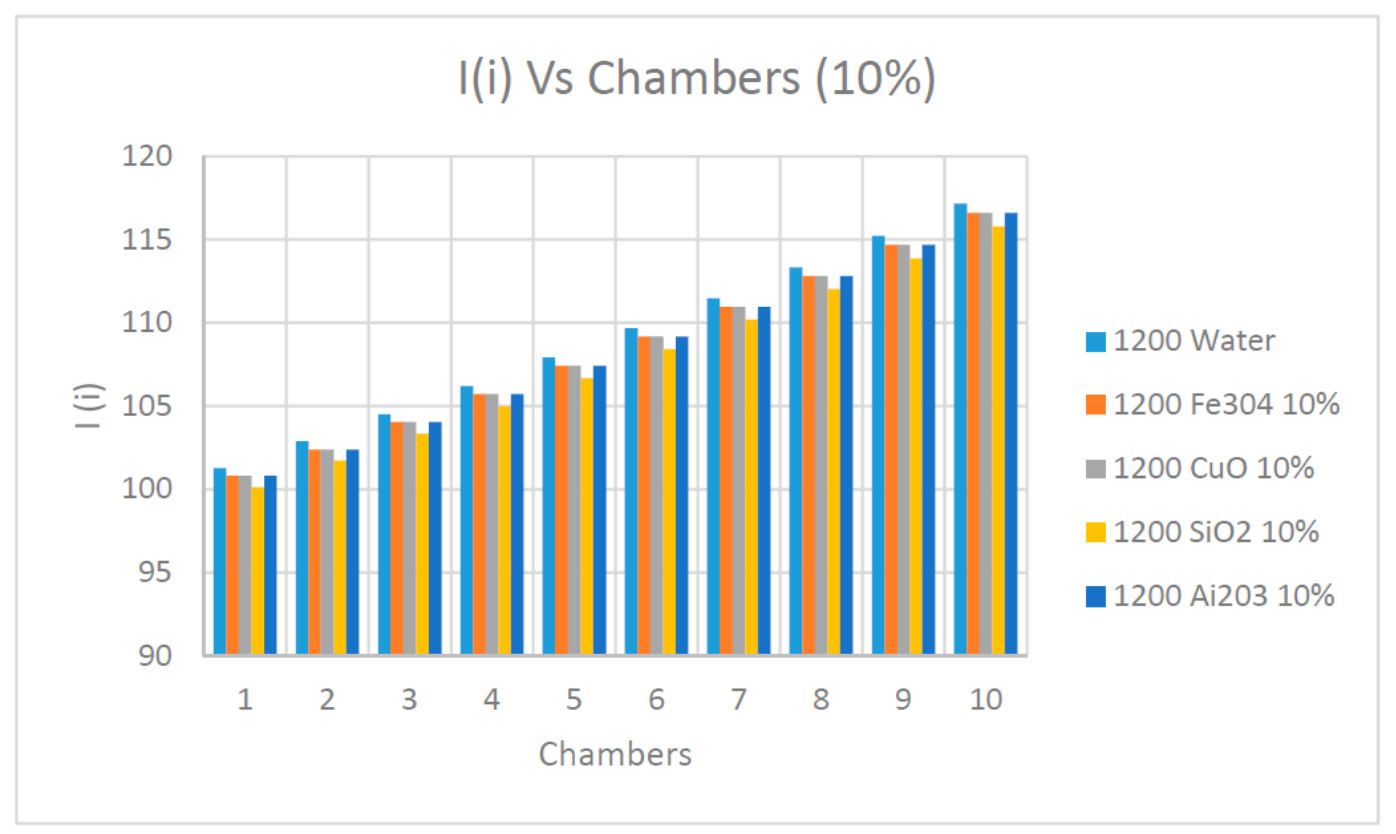

Figure 19. Irreversibility $(\mathrm{Btu} / \mathrm{lb})$ at $1200 \mathrm{w} / \mathrm{m}^{2}$ at $10 \%$ concentration and different nanofluids. 


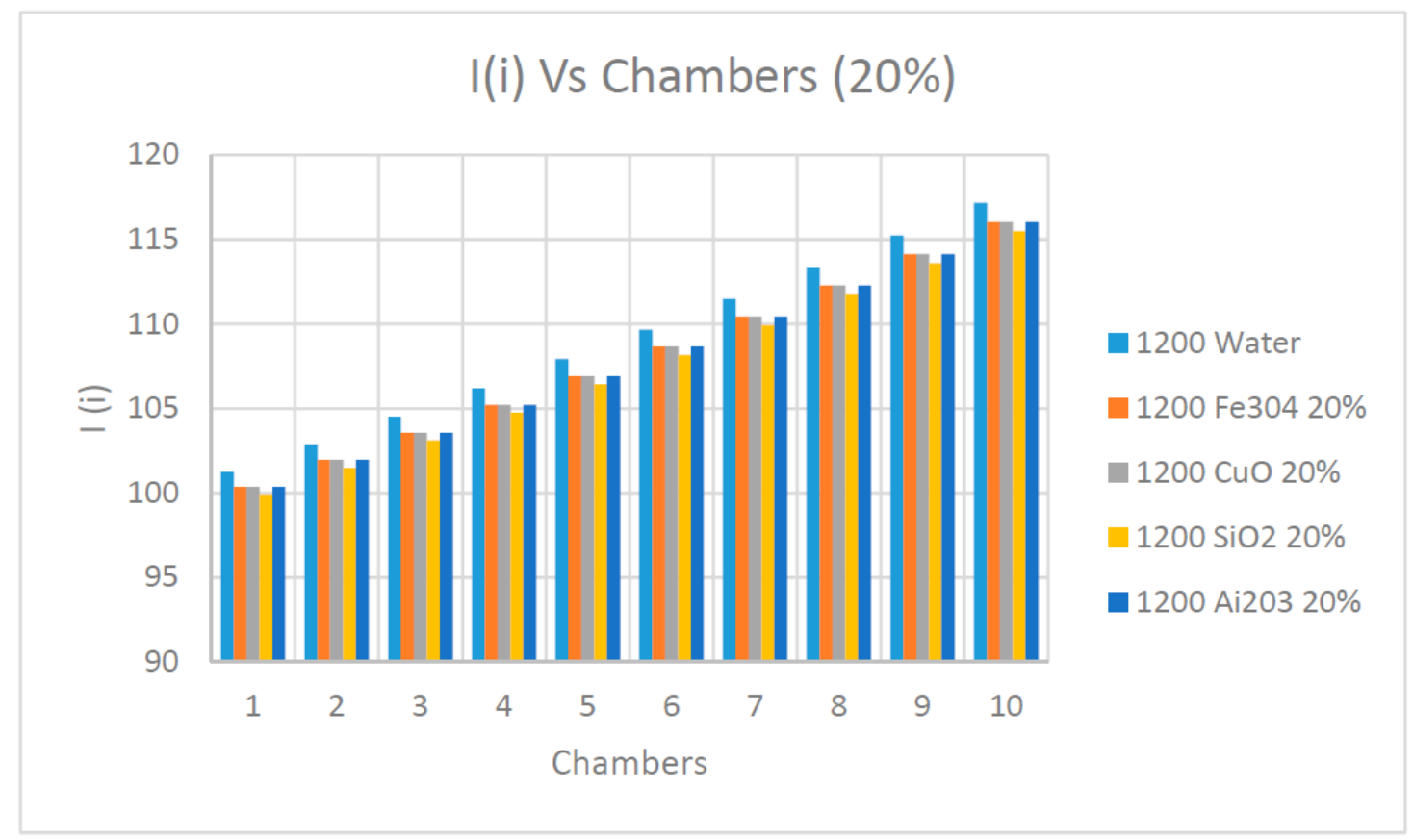

Figure 20. Irreversibility (Btu/lb) at $1200 \mathrm{w} / \mathrm{m}^{2}$ at $20 \%$ concentration and different nanofluids.

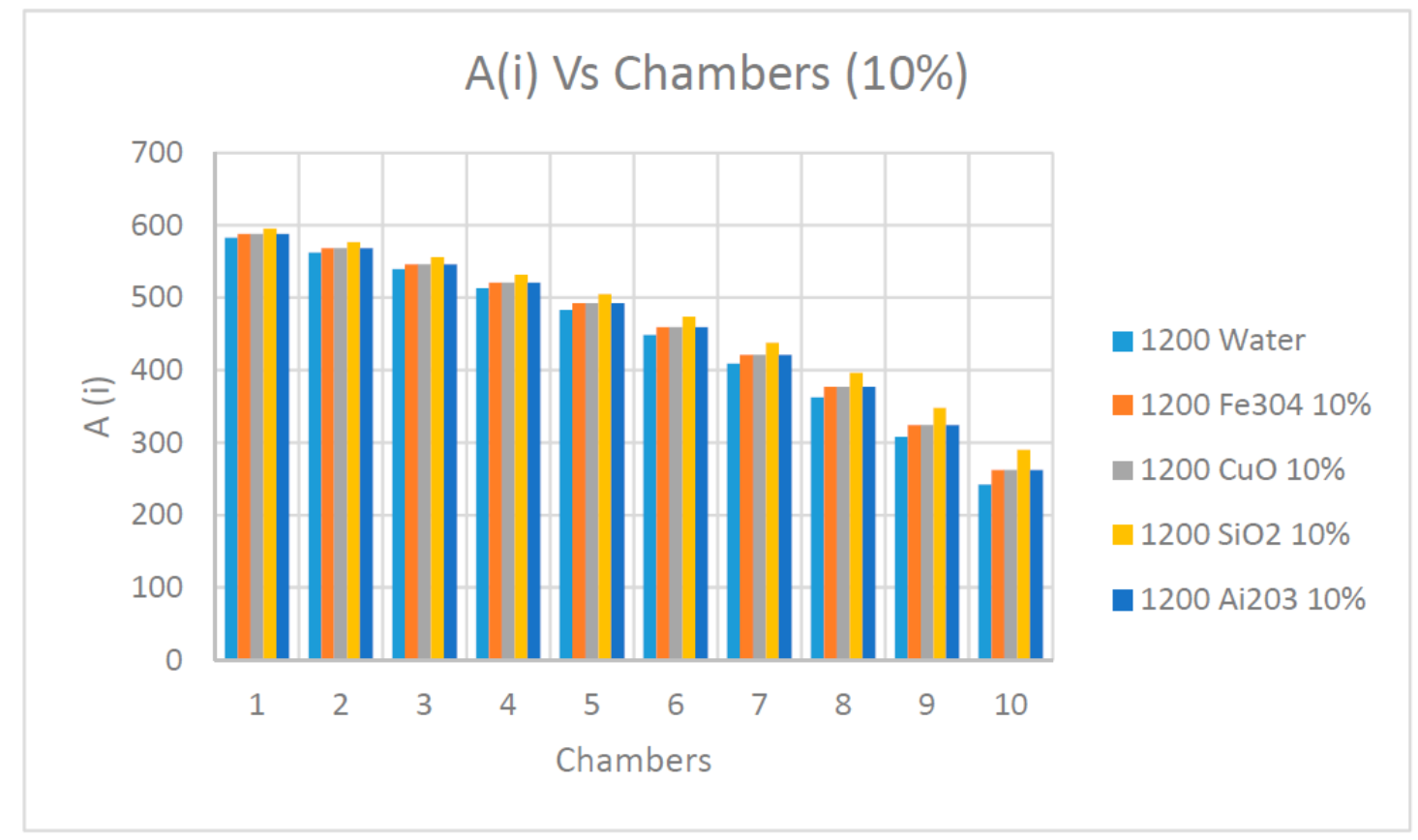

Figure 21. Availability (Btu/lb) at $1200 \mathrm{w} / \mathrm{m}^{2}$ at $10 \%$ concentration and different nanofluids.

As observed in Figures 21 and 22 and as previously discussed elsewhere in this paper, the availability determined by Equation (15) diminished progressively along the flashing chambers and reached the lowest value at the last chamber. It also appears that the nanofluids concentrations had little impact on the availability during the process of the flashing. On the other hand, it can be observed from the results presented in these figures that the nanofluid $\mathrm{SiO}_{2}$ had the highest availability among the other nanofluids, including water as the base fluid in the flashing chambers.

Finally, in order to investigate the impact of the nanofluids on the brine out flow from each chamber, Figures 23 and 24 were plotted at different nanofluids under investigation where the solar radiation was at $1200 \mathrm{w} / \mathrm{m}^{2}$. In general, the brine outflow decreased progressively across the flashing 
chambers and was the lowest at the last chamber. This was expected since at each chamber, an amount of vapor was flashed, which reduced the brine flow progressively along the flashing chambers. It also appears from these data that the higher the concentration of the nanofluids, the higher the brine flow across the flashing chamber, which was also expected. It was also observed that the nanofluid $\mathrm{Ai}_{2} \mathrm{O}_{3}$ produced the highest brine flow across the flashing chamber among the nanofluids under investigation, including water as the base fluid.

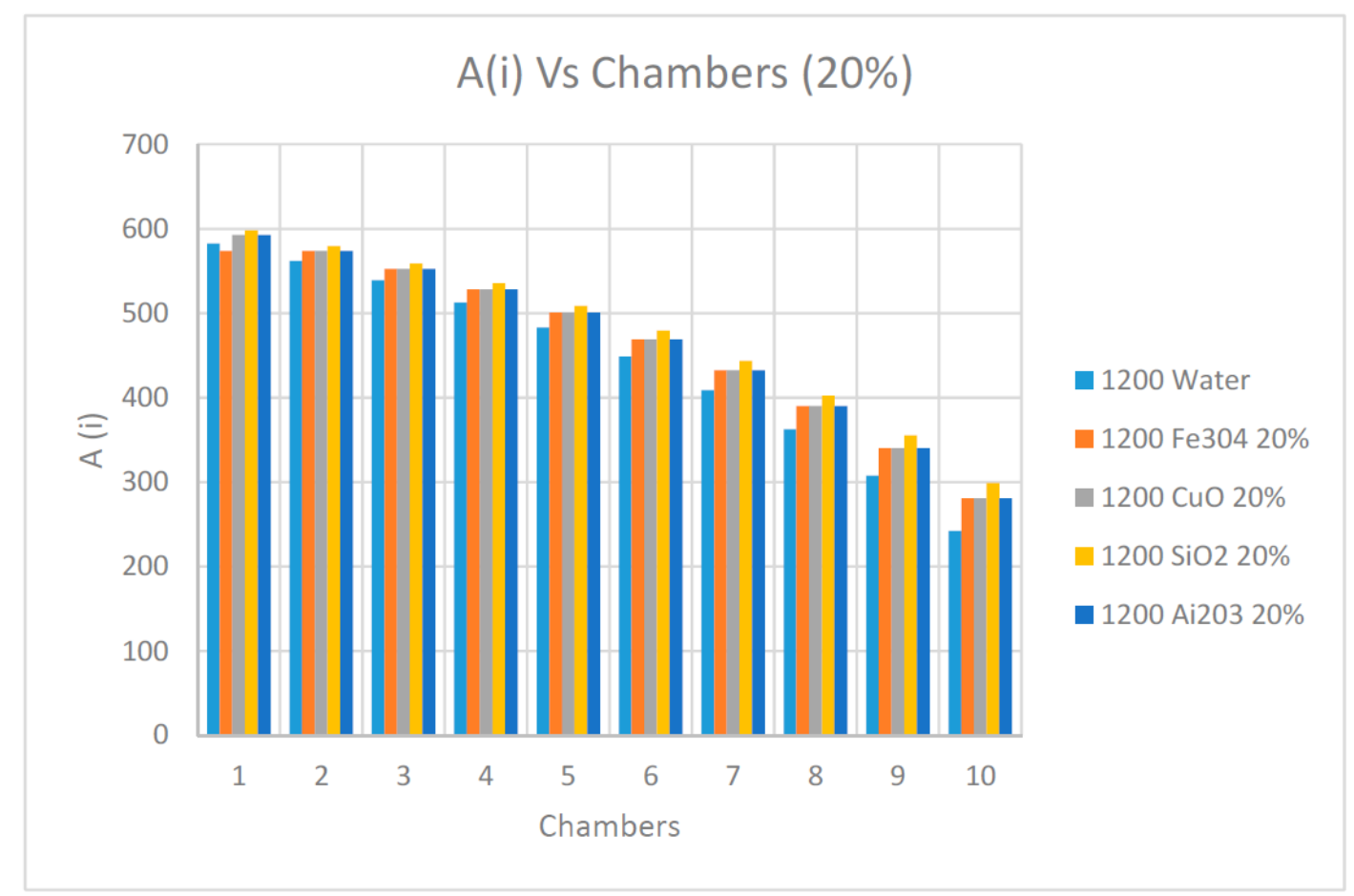

Figure 22. Availability (Btu/lb) at $1200 \mathrm{w} / \mathrm{m}^{2}$ at $20 \%$ concentration and different nanofluids.

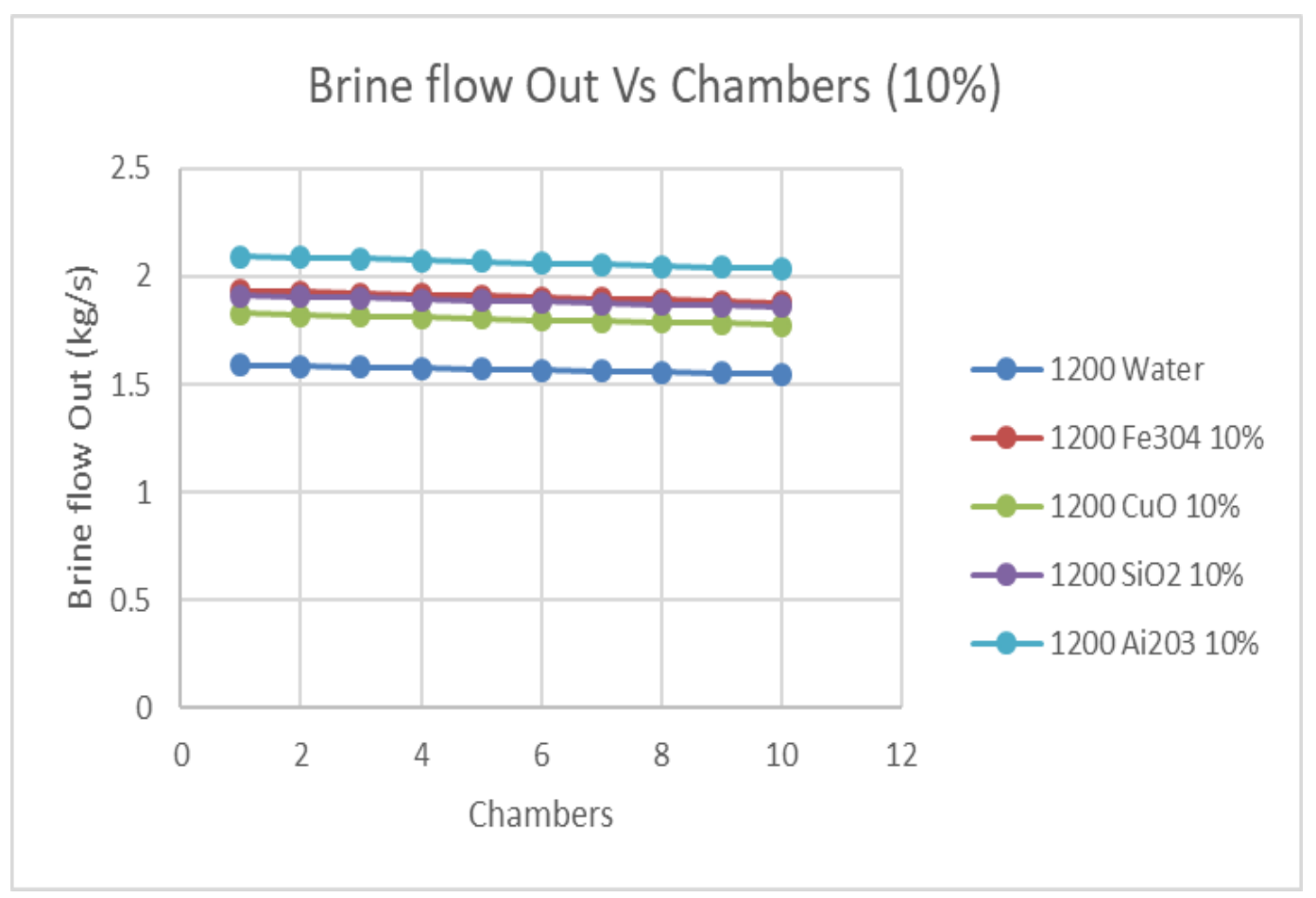

Figure 23. Brine flow out $(\mathrm{kg} / \mathrm{s})$ at $1200 \mathrm{w} / \mathrm{m}^{2}$ at $10 \%$ concentration and different nanofluids. 


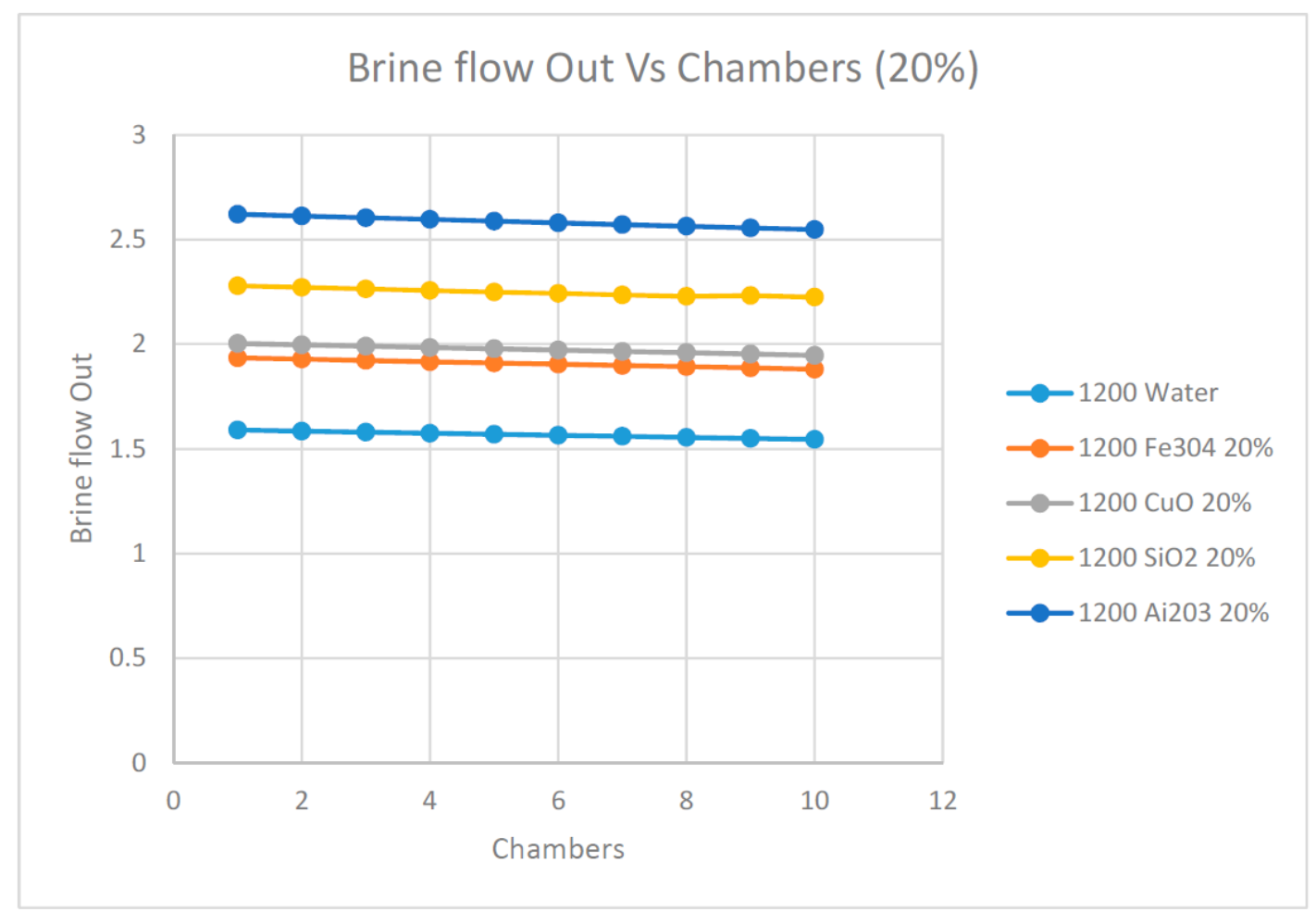

Figure 24. Brine flow out $(\mathrm{kg} / \mathrm{s})$ at $1200 \mathrm{w} / \mathrm{m}^{2}$ at $20 \%$ concentration and different nanofluids.

Finally, it is worth mentioning that lower nanofluids concentrations did not yield the minimum thermal capacities needed for the flashing process of the brine; therefore, $10 \%$ and $20 \%$ nanofluid concentrations were used. Their impact on the pump power was taken into consideration while calculating the availability and irreversibility during the flashing process.

\section{Model Validation}

In order to validate the numerical model presented herein in Equations (1)-(16), work research published in the literature on the subject in question was examined, and it was found that very limited experimental data were published on the subject of desalination by the flashing technique. Only water as the base heat transfer fluid was reported. However, to the best of our knowledge, none was reported in the literature on the desalination by flashing technique using nanofluids. Therefore, it was decided to use the data published in reference Nannaronea et al. [7] for validation purposes. Figure 25 has been constructed to show a comparison between results predicted by this model for the flashed flow and the data reported in reference [7]. As can be observed from this figure, the amount of the produced distillate by flashing decreased along the different chambers/stages progressively and consequently, the flash temperature and pressure profiles decreased. This is due to the increase of the heat of vaporization at lower saturation temperatures and consequently, less amount of vapor was extracted from brine.

Figure 25 depicts the flashed flow reduction ratio across the different flashing chambers from the first to the last chamber. The data reported by reference [7] on the reduction ratio of the flashed flow were compared to the predicted results by this model chamber by chamber. The comparison shown in this figure clearly shows that the model compared well with the data of reference [7]; however, the figure shows that data were underpredicted by our model. This can be attributed to the energy lost to the surroundings in the form of irreversible energy during the flashing process taking place in each chamber and this was not fully taken into account by the mass and energy balances built in the present model, as can be seen in Equation (16). 


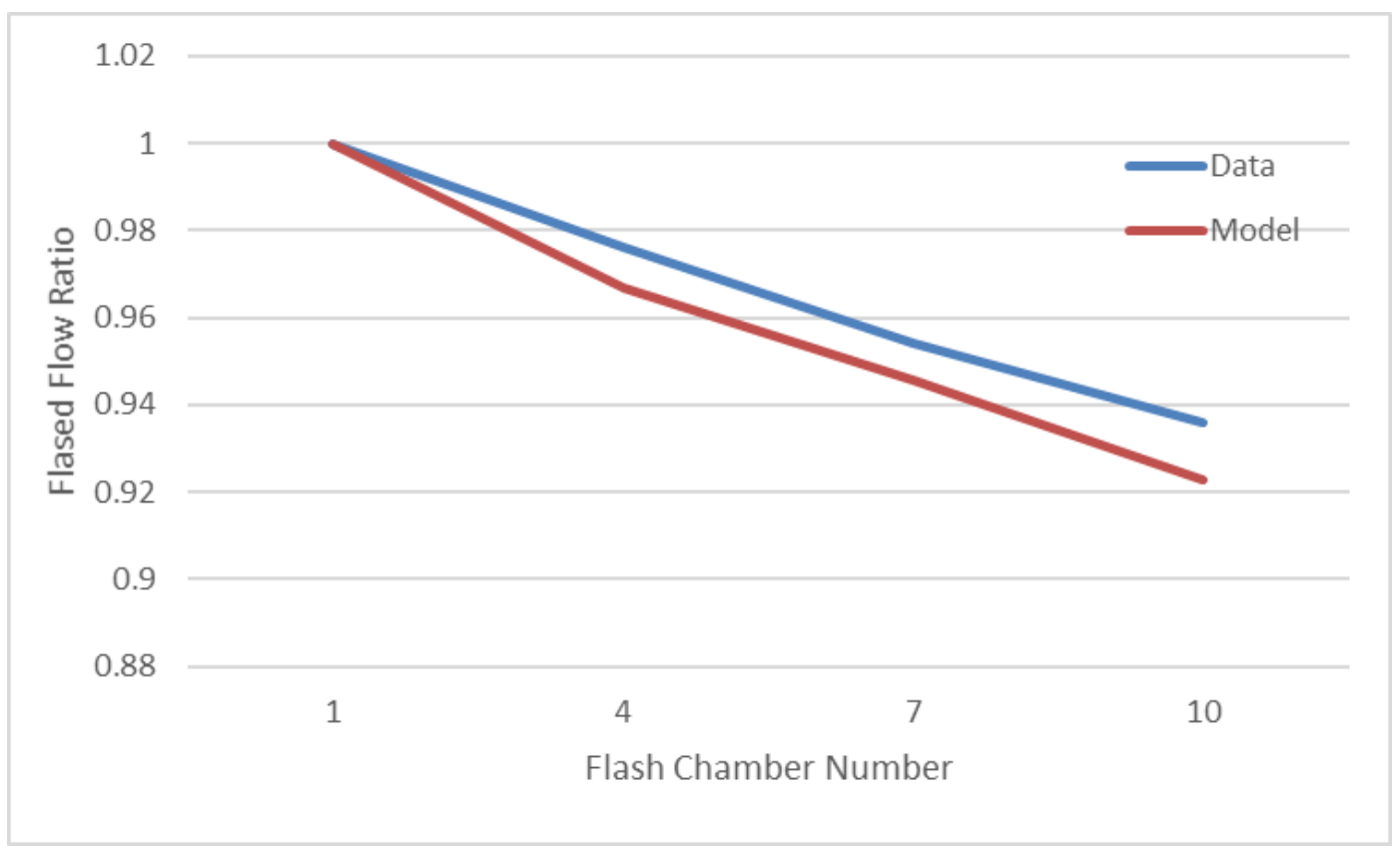

Figure 25. Comparison between model prediction and data [7].

\section{Conclusions}

A novel concept was presented in this paper for the MSF process, that implements PV-Thermal solar panels using hot heat transfer fluid with nanofluids. A mathematical and numerical model to describe the PV-thermal solar to drive the multistage flashing chamber process was presented. The model proposed was established after the mass and energy conservation equations written using the finite control volume approach with integrated thermal and thermophysical properties of the water and nanofluids as heat transfer fluids. The nanofluids under investigation are $\mathrm{Ai}_{2} \mathrm{O}_{3}, \mathrm{CuO}, \mathrm{Fe}_{3} \mathrm{O}_{4}$ and $\mathrm{SiO}_{2}$. The flashing process was studied under various conditions, including different solar radiations, brine concentrations and nanofluids volumetric concentrations, as well as different flashing chamber temperatures and pressures. Solar radiations were taken as $500 \mathrm{w} / \mathrm{m}^{2}, 750 \mathrm{w} / \mathrm{m}^{2}, 1000 \mathrm{w} / \mathrm{m}^{2}$ and finally, $1200 \mathrm{w} / \mathrm{m}^{2}$. The nanofluids volumetric concentrations considered varied from $1 \%$ through $20 \%$.

There was clear evidence that the higher the solar radiation, the higher the flashed flow produced. The results also clearly show that the irreversibility was reduced by using nanofluid $\mathrm{Ai}_{2} \mathrm{O}_{3}$ at higher concentration of $10 \%$ to $20 \%$ compared to water as base heat transfer fluid. It was found that the highest irreversibility was experienced when water was used as the base fluid and the lowest irreversibility was associated with nanofluid $\mathrm{SiO}_{2}$. The irreversibility increase depended on the type of nanofluid and their thermodynamic properties. Furthermore, the higher the concentration of $\mathrm{Ai}_{2} \mathrm{O}_{3} ; 10 \%$ to $20 \%$, the higher the availability at the last flashing chamber. However, the availability was progressively reduced along the flashing chambers and was evident at the last flashing chamber. It was observed that the nanofluid $\mathrm{SiO}_{2}$ has the highest availability among the other nanofluids and water as the base fluid across the flashing chambers.

The results presented in this paper demonstrate that it is possible to increase the preheating process quality through the increase of the flashing chamber temperatures which, in turn, improves the plant thermal efficiency. The present study demonstrates an added value to the research in the thermal desalination by the use of solar energy, solar PV-Thermal panels as the driving force to the evaporation flashing process instead of a steam boiler. This approach represents a step forward towards the sustainability and reduction of global warming effects.

The predicted results were compared to the experimental data published in the literature. The comparison showed that the model fairly predicted the data under consideration. Finally, we 
believe that future studies should look into other nanofluids as heat transfer fluids at different volumetric concentrations and brine with different salt concentrations.

Funding: This research received no external funding.

Acknowledgments: The research work presented in this paper was made possible through the support of the Catholic University of Cuenca.

Conflicts of Interest: The author declares that there is no conflict of interest.

\section{Nomenclature}

$\begin{array}{ll}A_{q} & \text { the flow availability } \mathrm{kj} / \mathrm{kg} \\ C p & \text { the specific heat } \mathrm{kj} / \mathrm{kg} \mathrm{k} \\ D T_{\text {Stage }} & \text { the stage temperature difference } \\ \Delta H_{\text {evar }} & \text { the stage enthalpy difference } \mathrm{kJ} / \mathrm{kg} \\ G & \text { Total Solar radiation incident on the PV module } \\ H & \text { enthalpy } \mathrm{kj} / \mathrm{kg} \\ I j & \text { Irreversibility } \mathrm{kJ} / \mathrm{kg} \\ m & \text { mass flow rate } \mathrm{kg} / \mathrm{s} \\ \text { Qin } & \text { Energy received due to solar irradiation } \\ \text { Qconv } & \text { Energy loss due to Convection } \\ Q \text { Qelect } & \text { Electrical power generated } \\ \text { Sc } & \text { salt concentration, g/kg } \\ \text { Sj } & \text { the entropy of the flashing process at each stage } \mathrm{Kj} / \mathrm{kg} . \mathrm{K} \\ S p & \text { Total area of the PV module } \\ t & \text { time } \\ \text { Tj } & \text { Flashing chamber temperature, } \mathrm{K} \\ \text { Tamb } & \text { ambient temperature } \\ \text { Greek Symbols } & \\ \alpha & \text { the thermal diffusivity } \\ \Phi & \text { the nano particles volumetric concentration. } \\ \rho & \text { density, kg/m }{ }^{3}\end{array}$

\section{References}

1. El-Nashar, A.M. The economic feasibility of small solar MED seawater desalination plants for remote arid areas. Desalination 2001, 134, 173-186. [CrossRef]

2. Mohamed, A.; Eldean, S. Design and Simulation of Solar Desalination Systems. Ph.D. Thesis, Energy Engineering to Faculty of Petroleum \& Mining Engineering Suez Canal University, Ismailia, Egypt, 2011.

3. Qiblawey, H.M.; Banat, F. Solar thermal desalination technologies. Desalination 2008, 220, 633-644. [CrossRef]

4. Fath, H. Desalination Technology: The Role of Egypt in the Region; Fifth International Water Technology Conference: Alexandria, Egypt, 2000.

5. Eltawil, M.A.; Zhengming, Z.; Yuan, L. A review of renewable energy technologies integrated with desalination systems. Renew. Sustain. Energy Rev. 2009, 13, 2245-2262. [CrossRef]

6. Kalogirou, S.A. Solar thermal collectors and applications. Prog. Energy Combust. Sci. 2004, 30, $231-295$. [CrossRef]

7. Nannaronea, A.; Torob, C.; Sciubba, S. Multi-Stage Flash Desalination Process: Modeling and Simulation. In Proceedings of the Ecos 2017-the 30th International Conference on Efficiency, Cost, Optimization, Simulation and Environmental Impact of Energy Systems, San Diego, CA, USA, 2-6 July 2017; pp. 1-12.

8. Al-Fulaij, H.F. Dynamic Modeling of Multistage Flash (MSF) Desalination Plan. Ph.D. Thesis, University College London (UCL), London, UK, 2011.

9. Al-Nory, M.T.; Graves, S.C. Water desalination supply chain modeling and optimization: Case of Saudi Arabia, 2013 International Desalination Association. IDA J. Desalin. Water Reuse 2013, 5, 64-72. [CrossRef]

10. Bin Amer, A.O. Development and optimization of ME-TVC desalination system. Desalination 2009, 249, 1315-1331. [CrossRef] 
11. Nigim, T. Computational modelling of thermofluidic flashing in MSF desalination. Ph.D. Thesis, The National University of Ireland, Galway, Ireland, 2017.

12. Kabeel, A.E.; El-Said, E.A. Applicability of flashing desalination technique for small scale needs using a novel integrated system coupled with nanofluid-based solar collector. Desalination 2014, 333, 10-22. [CrossRef]

13. Garg, K.; Khullar, V.; Das, S.K.; Tyagi, H. Performance evaluation of a brine-recirculation multistage flash desalination system coupled with nanofluid-based direct absorption solar collector. Renew. Energy 2018, 122, 140-151. [CrossRef]

14. Yang, D.J.; Yuan, Z.F.; Lee, P.H.; Yin, H.M. Simulation and experimental validation of heat transfer in a novel hybrid solar panel. Int. J. Heat Mass Transf. 2012, 55, 1076-1082. [CrossRef]

15. Lalovi, B.; Kiss, Z.; Weakliem, H.A. Hybrid amorphous silicon photovoltaic and thermal solar-collector. Sol. Cells 1986, 19, 131-138. [CrossRef]

16. Sami, S. Prediction of Performance of a Novel Concept of Solar Photovoltaic-Thermal Panel and Heat Pipe Hybrid System. Int. J. Mod. Stud. Mech. Eng. 2019, 5, 1-26. [CrossRef]

17. Sami, S.; Campoverde, C. Dynamic Simulation and Modeling of a Novel Combined Hybrid Photovoltaic-Thermal Panel Hybrid System. Int. J. Sustain. Energy Environ. Res. 2018, 7, 1-23. [CrossRef]

18. Sami, S.; Marin, E. Modelling and Simulation of PV Solar-Thermoelectric Generators using Nano Fluids. Int. J. Sustain. Energy Environ. Res. 2019, 8, 70-99. [CrossRef]

19. Allen, C. Magnetic Field Enhancement Thermal Conductivity Analysis of Magnetic Nanofluids. Master's Thesis, University of Texas at Arlington, Arlington, TX, USA, 2015.

20. Al-Waeli, A.H.; Chaichan, M.T.; Kazem, H.A.; Sopian, K.; Safaei, J. Numerical study on the effect of operating nanofluids of photovoltaic thermal system $(\mathrm{PV} / \mathrm{T})$ on the convective heat transfer. Case Stud. Therm. Eng. 2018, 12, 405-413. [CrossRef]

21. John, M. Fundamentals of Engineering Thermodynamics; John Wiley \& Sons, Inc.: Hoboken, NJ, USA; p. 220. ISBN 978-0-471-78735-8.

22. Sami, S. Modelling and Simulation of Performance of Nanofluids in PV-Thermal Solar Panel Collectors. J. Appl. Res. 2019, 5, 1. [CrossRef]

23. Sami, S. Modeling and Simulation of a Novel Combined Solar Photovoltaic-Thermal Panel and Heat Pump Hybrid System. Clean Technol. 2018, 1, 89-113. [CrossRef]

24. Rudyak, V.Y.; Minakov, A.V. Thermophysical properties of nanofluids. Eur. Phys. J. E 2018, 41, 15. [CrossRef] [PubMed] 